\title{
Impact of European Integration on Institutional Development
}

\author{
Nina Schönfelder \\ University of Hagen, Hagen, Germany \\ Helmut Wagner \\ University of Hagen, Hagen, Germany
}

\begin{abstract}
This paper investigates institutional development induced by European integration. We estimate a dynamic panel data model wherein institutional development is measured as positive changes in the Worldwide Governance Indicators, which are explained by the status of the European countries, for example, being a member of the euro area or an EU member state or a candidate country of the European Union, and additional controls. We confirm a positive effect arising from prospective EU membership, although being an EU member state does not influence the institutional development path. For members of the euro area, there is robust evidence for institutional deterioration in one particular area, namely control of corruption.
\end{abstract}

\section{JEL Classifications: F55, O43}

Keywords: Institutional Development, Transition Economies, European Integration, Euro Area, Panel Data

\footnotetext{
* Corresponding Author: Nina Schönfelder; University of Hagen, Universitätsstraße 11, 58097 Hagen, Germany; Tel: +49 2331987 2379, Fax: +49 2331987391, E-Mail: nina.schoenfelder@fernuni-hagen.de.

Co-author: Helmut Wagner; University of Hagen, Universitätsstraße 11, 58097 Hagen, Germany; Tel: +49 23319872640, Fax: +49 2331 987391, E-Mail: helmut.wagner@fernuni-hagen.de. 


\section{Introduction}

The institutional development and transformation process in the transition countries of Central and Eastern Europe are widely recognized to have paved the way for the considerable and ongoing enlargement of the European Union (EU). Furthermore, the prospect for European countries to join the EU creates additional incentives for those countries to strengthen their economic and political institutions; the EU thus serves as an outside anchor for the reform process (Berglöf and Roland 1997). On the one hand, conditionality of EU accession (the Copenhagen criteria) is an obstacle that candidate countries have to overcome. On the other hand, the conditionality provides the transition countries' governments with guidelines for reforms. The adoption of the euro does not have direct legal effects on institutional development, but economic implications are possible.

One aim of this paper is to assess empirically whether the prospect for European countries to join the EU inclines them to strengthening their institutions; certainly, a positive impact would be expected from this prospect. The more challenging question concerns the future of a country's institutional development after becoming an EU member state, preparing for the introduction of the euro and finally becoming a member of the euro area. Some empirical studies explore the link between prospective EU membership and institutional development in the transition countries of Central and Eastern Europe. Two other strands of literature analyze the impact of euro-area membership. The first focuses on reforms in product and labor market regulations induced by euro-area membership. The second examines the euro-area membership's influence on fiscal deficits. However, there is a lack of empirical literature on the link between EU membership with the preparation to introduce the euro and institutional development. The relationship between euro-area membership and institutional development is also not analyzed in the empirical literature. The aim of our paper is to shed light on these relationships.

In the 1992 Maastricht Treaty, the EU committed to promote economic and social progress which is balanced and sustainable. Among others, catching up in the institutional development of member states could contribute to long-term income convergence in the EU and the euro area. Roland (2000) emphasizes the importance of adequate institutions for economic growth in transition countries: the experience of transition from socialism to capitalism in former socialist economies shows that the structural policies 
of liberalization, stabilization, and privatization should be accompanied by adequate institutions to deliver successful outcomes.

According to the development and growth literature, there is a positive link between a country's institutional development and its development stage and income growth. Since the contributions by North $(1981,1990)$, many attempts have been made to verify this hypothesis empirically: see, for example, the co-authored writings of Acemoglu (Acemoglu and Robinson 2012, Acemoglu and Johnson 2005, Acemoglu et al. 2005). Several surveys provide an overview of this vast body of empirical literature (Aron 2000, Jütting 2003, Shirley 2005, Haan 2007, Kohn 2009). Some of these studies deal particularly with institution building and its growth effects in transition countries (Beck and Laeven 2006). In the present paper, we do not review this literature or its critics' arguments ${ }^{1}$ (see, e.g., Glaeser et al. 2004, Voigt 2013) because such a task goes beyond the scope of this paper. ${ }^{2}$ Even if institutional development is socially desirable in a country, reforms may not be implemented because of problems covered by public choice theory. These problems could be, for example, strategic decisions of self-interested politicians and national or international distributional conflicts (Drazen 2000). European integration could help European countries overcome these obstacles.

In this paper, the term institutions is defined broadly, and we do not explore specific policy measures or institutional arrangements. To measure the level of institutional development, we employ the six Worldwide Governance Indicators (WGIs) devised by Kaufmann et al. (2010). Institutional development is measured as positive changes in the WGIs. The paper is organized as follows. Section II discusses how European integration matters for institutional development from a theoretical point of view. Moreover it provides an overview of the related empirical literature. The data on institutional development and countries' status are explained and descriptive statistics are presented in Section III. Section IV describes our empirical model and the estimation method. Section $\mathrm{V}$ presents and discusses the results and provides various robustness checks. Our findings confirm a positive effect of prospective EU membership for most WGIs and econometric specifications. In particular, prospective EU membership reduces the

\footnotetext{
${ }^{1}$ However, some criticism could also be pertinent to our paper-for example, the endogeneity problem and the issues in measuring institutinal development. We address some of these problems in the subsequent sections.

2 From this literature, two empirical papers particularly shaped our selection of control variables. Dollar and Kraay (2003) find a substantial partial effect of changes in trade on changes in Gross Domestic Product (GDP) growth. Rigobon and Rodrik (2005) estimate the interrelationships between rule of law, democracy, openness, and income. They find some indication that higher income produce better institutions (i.e., better rule of law and democracy). Regarding openness, they find an asymmetric effect of openness on economic and political institutions. Openness improves rule of law but worsens democracy.
} 
persistence of institutional development. Being a EU member state preparing to introduce the euro does not influence a country's institutional development path. However, there is robust evidence for worsened control of corruption for euro-area members. Section VI concludes.

\section{Literature Review}

\section{A. European integration as a driver for institutional development}

In this section, we review the theoretical literature in terms of answers to the following three central questions. First, does the EU influence institutional development? Second, what role does the EU conditionality play in the accession process? Third, does membership in the euro area matter for institutional development?

The first question posed in this section-concerning the EU's influence on institutional development - relates to the literature on the EU as an external or outside anchor. Crombrugghe et al. (1996) outline the motivation for the rapid integration of transition countries into the EU on the basis of self-fulfilling expectations. A transition country's expectation of EU entry can coordinate expectations toward a fast-growth, catching-up equilibrium. The premise is that the transition countries and the EU transparently and strongly commit to reforms and enlargement, respectively. Roland and Verdier (2003) develop a model to analyze law-enforcement problems in transition economies with coordination problems and multiple equilibria. They show that accession to the EU provides a mechanism to overcome a bad equilibrium in accessing countries. The prospect of EU membership without conditionality is sufficient to result in a good equilibrium if the accessing country is small enough relative to the $\mathrm{EU}$ in economic terms. Mattli and Plümper (2004) provide a formal model that explains how prospective EU membership drives regulation in applicant countries beyond their equilibrium level of regulatory quality. They show that the gains in voter support for the government from accepting EU membership conditionality increases with the level of democracy. Hence, in more democratic countries, the level of regulatory quality is higher if they have the option to become a member state. Brücker et al. (2005) model the Soft Budget Constraint (SBC) problem in transition economies as a war of attrition between the applicant 
countries' governments and firms. The SBCs represent a dynamic commitment problem of a government or bank opting not to bail out firms in financial distress. Brücker et al. (2005) show that outside conditionality can foster SBC hardening.

The second question posed in this section concerns the role that the EU conditionality played in the accession process. This can be discussed from either a normative or a positive point of view, that is, how the EU conditionality should be shaped versus how it was, in fact, applied. The principle of conditionality requires that clear and equal accession conditions apply to all countries, their progress is evaluated coherently and without discrimination by the EU, and their accession status is directly dependent upon these evaluations (Kochenov 2008). The EU conditionality, if designed and conducted properly, has several positive effects (Crombrugghe et al. 1996). First, it provides transition countries' governments with guidelines for reforms. Second, it introduces competition between political parties in a transition country for the best reforms to meet those conditions if the public regards EU membership as desirable. Third, it enables transition countries to make a sovereign decision - through a cost-benefit analysis — on whether it is worth entering the EU.

Following the collapse of the Eastern Bloc, the European Community launched several aid and trade programs (PHARE, Europe agreements, etc.) with explicit or implicit political conditionality regarding the rule of law, democracy, and economic liberalization. Weber (1995) shows that the conditionality was not a paper tiger in the early 1990s. In several countries, programs were suspended or delayed in response to non-compliance. For the conditionality principle to work, the EU needed to move away from engaging in a deeply politicized practice of enlargement regulation to an increasingly legal enlargement regulation in the 1990s (Kochenov 2008). The Copenhagen European Council formulated accession criteria in 1993 called Copenhagen criteria. ${ }^{3}$ In a jurisprudential analysis of the EU conditionality toward the new Central and Eastern European member states, Kochenov (2008) shows that the EU successfully formed a framework of instruments for the application of the conditionality principle regarding the criteria democracy and rule of law. However, he concludes that the application of the instruments was a resounding failure, if it was applied at all (Kochenov 2008), at least in the areas of democracy and rule of law. A country's accession status

\footnotetext{
"Membership requires that the candidate country has achieved stability of institutions guaranteeing democracy, the rule of law, human rights and respect for and protection of minorities, the existence of a functioning market economy as well as the capacity to cope with competitive pressure and market forces within the Union. Membership presupposes the candidate's ability to take on the obligations of membership including adherence to the aims of political, economic and monetary union." (European Council 6/22/1993, 7.A.iii))
} 
was not linked to the Commission's evaluation, so the conditionality principle was de facto removed in the areas of democracy and rule of law (Kochenov 2008).

The third question concerns the influence of prospective and current euro-area membership on institutional development. Berglöf et al. $(2008,2012)$ present a model wherein a member of a club, say the EU, has incentives to reform beyond its privately optimal level. This model can show that among more heterogeneous members of the organization, a club-in-the-club arrangement (e.g., the euro area) is more likely to emerge and that even weak members of the outer club (the EU) reform to meet the accession criteria of the inner club (the euro area). The creation of a common currency area with strict criteria for joining (the Maastricht criteria) results in a "club-in-the-club" that remains open to every country willing to reform and therefore join the euro area (Berglöf et al. 2012).

Alesina et al. (2010) describe two channels by which euro-area membership could accelerate deregulation and liberalization in product and labor markets: the competition channel and the adjustment channel. The former establishes a relationship between greater competition resulting from the single market and the cost of regulation. If a common currency is a necessary condition for having a truly common market, then the protection of insider firms and workers through anti-competitive regulation would become more costly and visible to consumers and voters. The second channel becomes relevant whenever a country is losing competitiveness. The common currency eliminates the possibility of strategic devaluations when real wage growth is out of line with productivity growth. Hence, adjustment has to be made by real wage adjustments and labor mobility and flexibility (Alesina et al. 2010). This argument is related to the There is No Alternative (TiNA) argument: by introducing the euro, member countries lose the ability to use monetary policy to accommodate asymmetric shocks. Instead, adjustment has to come via a boom or recession. The more flexible the labor market is, the less painful this adjustment will be in terms of unemployment (Bean 1998, Alesina et al. 2010). However, some economists also argue that the euro could hamper labor market reforms. Reforms on the supply side entail negative short-term effects on employment. These can be alleviated by expansionary aggregate demand policies. In the euro area, member countries are constrained by the Stability and Growth Pact in pursuing fiscal policy. Hence, the short-term costs of labor market reforms are higher in a common currency area, and reforms may become politically unfeasible (Bean 1998, Alesina et al. 2010). Saint-Paul and Bentolila (2001) argue that large-scale labor market reforms will be more difficult to implement, whereas some gradual reforms toward flexibility are 
easier to implement within the euro area.

Fernández-Villaverde et al. (2013) used a case study to show that economic reforms were abandoned and institutions deteriorated after introduction of the euro in Spain, Ireland, Greece, and Portugal. First, capital flows relaxed the economic constraints under which agents (e.g., a government, a bank manager) were acting, which reduced pressure for reforms. Second, these capital inflows hindered the principal (e.g., voters, shareholders, investors) in extracting signals about the agent's performance. Germany did not experience a loosening of its financing conditions because of the introduction of the euro, and it faced a stagnant economy. Hence, Germany implemented far-reaching structural reforms so that the divergence in institutions between Germany and the other peripheral countries increased after the introduction of the euro (Fernández-Villaverde et al. 2013).

To sum up the literature, there could be indirect effects on institutional reforms arising from the Maastricht criteria. After EU member states introduce the euro, there are virtually no effective enforcement measures, so the incentives to undertake institutional reforms may disappear. However, the theoretical models on this matter offer ambiguous conclusions.

\section{B. Review of the empirical literature}

Some empirical studies exist on the link between prospective EU membership and institutional development in the transition countries of Central and Eastern Europe. Beck and Laeven (2006) identify a positive link between EU accession and the WGIs, although they do not control for reverse causality. Di Tommaso et al. (2007) treat institutional change as a multidimensional unobserved variable. Their results suggest that an external anchor, such as EU accession, can break the path dependence of institutional change to some extent. Using a Hausman-Taylor model, Schweickert et al. (2011) identify a positive link between institutional development and the pre-accession incentives provided by the EU and NATO. Mattli and Plümper (2004) estimate that applying to the EU accounts for approximately $40 \%$ of variance in regulatory quality between transition countries. Regulatory quality is measured by the average of the nine European Bank for Reconstruction and Development (EBRD) transition indicators. Moreover, Mattli and Plümper (2004) provide evidence that exogenous changes in the perceived likelihood of EU accession impact the pace of reforms. Countries facing the 
prospect of late accession implement significantly less reforms than their early-accession counterparts. Brücker et al. (2005) test whether accession candidate countries have a lower long-term labor to output ratio and adjust labor productivity faster to its long-run levels than other transition countries. This is an indicator for the hardening of SBCs, which EU accession can foster according to their model. Indeed, Brücker et al. find that in accession candidate countries, the speed of adjustment is significantly larger and labor productivity is significantly higher. The only paper that finds no significant effect of prospective EU membership on the development of economic institutions is that by Staehr (2011). While both prospective and actual memberships are shown to have positive effects on political reforms, this effect is insignificant or even negative. In our opinion, this result could be resolved as follows. Political freedom explains much of the progress in economic reforms, and political reforms are, in turn, influenced by actual and prospective EU memberships; hence, economic reforms are indirectly, rather than directly, determined by the EU enlargement process.

Two strands of literature analyze the impact of euro-area membership. The first focuses on reforms in the regulation of product and labor markets. The second examines the influence on fiscal deficits. Alesina et al. (2010) show that the euro accelerated reforms in product markets, accompanied probably by wage moderation in the labor market. Duval and Elmeskov (2005), Belke et al. (2007), and Belke and Vogel (2015) also contribute to this strand of literature. Investigating organization modes of the budget process, Gleich (2003) finds that procedures that contribute to reducing collective action problems have been associated with greater fiscal discipline. Hence, progress in the institutional structure of the budgeting process can facilitate compliance with the Maastricht criteria and the Stability and Growth Pact. Bayar and Smeets (2009) and Ballabriga and Martinez-Mongay (2007) also find that the Maastricht Treaty had a positive effect on fiscal balances. In contrast, Galli and Padovano (2008) and Mink and Haan (2005) do not find support for this thesis. Eijffinger and Stadhouders (2003) examine the relationship among inflation, the institutional design of monetary institutions, and the rule of law. They argue that legal arrangements are a necessary condition for central bank independence, but the actual application of law is much more important to achieve price stability. Institutional quality indicators are used as a proxy for rule of law and are shown to be significantly and negatively related to the inflation rate.

However, to our knowledge, there is no empirical literature on either the link between EU membership with preparation to introduce the euro and institutional development or on the relationship between euro-area membership and institutional development. The 
only evidence is provided by a case study by Fernández-Villaverde et al. (2013). The aim of our paper is to shed light on these relationships.

\section{Data}

\section{A. Worldwide governance indicators}

Numerous indicators have been considered to measure institutional development. They can be roughly classified into five categories: (1) quality of formal institutions, (2) measures of social capital, (3) measures of social characteristics, and (4) characteristics of political institutions, and (5) measures of political instability (Aron 2000). Moreover, one can distinguish between indicators for economic, legal, and political institutions. To measure institutional development in this paper, we employ the WGIs of the World Bank devised by Kaufmann et al. (2013). ${ }^{4}$ These indicators are widely used in research, covering the countries and years important for our analysis and measuring the quality of economic, legal, and political institutions.

The WGIs consist of six composite indicators capturing governance perception. The six dimensions of governance are Voice and Accountability (VaA), Control of Corruption (CoC), Government Effectiveness (GE), Political Stability and Absence of Violence (PSNV), Rule of Law (RoL), and Regulatory Quality (RQ). ${ }^{6}$ The WGIs are composed of several hundred variables obtained from surveys of firms and households as well as subjective assessments collected by commercial business providers, nongovernmental organizations, multilateral organizations, and other public sector bodies. The variables are clustered along the six dimensions of governance by an unobserved components model. The WGIs are normally distributed, with zero mean and ranging approximately from -2.5 to 2.5 (Kaufmann et al. 2010).

\footnotetext{
${ }^{4}$ The field of economic governance analyzes the performance of different institutions under different conditions, the evolution of these institutions, and the transitions from one set of institutions to another (Dixit 2008). The WGIs are important measures of institutional quality.

${ }^{5}$ To prove that the results of this analysis are robust with respect to the choice of indicator for institutional development, alternative indicators should be considered as the dependent variable. However, this goes beyond the scope of this paper as we already consider six dimensions of governance perception. Further analyses should be conducted in a follow-up study.

${ }^{6}$ For a detailed description of the WGIs' six dimensions and the methodology, see Kaufmann et al. (2010). PSNV is the acronym for Political Stability/No Violence.
} 
The indicators cover the years 1996 2012 and are available on a two-year basis until 2002 and on a yearly basis subsequently. Hence, we have to handle the missing data problem for the WGIs in 1997, 1999, and 2001. Since the lack of these WGIs depends neither on their value nor on the values of other variables in the dataset, they are missing completely at random. There are two simple ways to handle missing data in this case: Listwise deletion $^{7}$ and mean imputation. The former has several disadvantages. Since 3 out of 17 years are missing, deletion leads to a substantial reduction in the total number of observations. Even more information is lost if we calculate year-to-year changes in the WGIs as the sample would then be essentially cut to the 2003 2012 period. One possibility to mitigate this problem is to calculate two-year changes in the variables and skip the information for the years 2003, 2005, 2007, 2009, and 2011. This is carried out in Section VI.B as a robustness check. The second way to handle missing data is mean imputation. Accordingly, missing WGIs are replaced by the average value of the previous- and following-period WGIs for each country. The disadvantage of this method is that it could impact the distribution of the WGIs and therefore affect the co-variances with other variables. Nevertheless, we favor the latter approach to handle the missing WGI problem in order to retain as much information as possible.

There are several potential problems with the WGIs to discuss in terms of our use of cross-section and time dimension. As the WGIs are constructed to have a zero mean in each period, comparisons of WGIs over time could be a problem. Kaufmann et al. (2007) argue that this could indeed be problematic for absolute changes in WGIs. However, relative comparisons of individual countries or country groups are not affected and are therefore valid, even if global averages have changed over time. Indeed, global averages of the underlying sources show little evidence of significant trends, as Kaufmann et al. show in previous works. Hence, this allows the interpretation of relative changes as absolute changes in individual or groups of countries (Kaufmann et al. 2007). A further point of criticism is that the WGIs might be too imprecise to yield sensible comparisons over time or countries. This criticism could be applied to many institutional development indicators because of measurement errors. However, the WGIs aggregate the existing indicators and hence their information about governance (Kaufmann et al. 2007).

\footnotetext{
${ }^{7}$ Listwise deletion means reducing the sample to complete observations. For a discussion on missing data assumptions and their consequences, see Cameron and Trivedi (2007).

${ }^{8}$ This and other critiques are discussed in Kaufmann et al. (2007).
} 


\section{B. Status dummy variables}

To indicate the status or official relationship between our sample countries and the $\mathrm{EU}$ and the euro area, we construct a set of dummy variables. The sample covers 56 countries - of which 33 are European countries - that have at least been a potential candidate at some point in time (1996 2012) according to the classification in Table 1. The remaining 23 countries are other Organization for Economic Co-operation and Development (OECD) countries and European and Central Asian developing countries, as defined by the World Bank, that serve as the control group in this paper. A full list is presented in the Appendix. 
Table 1. Classification of the status dummy variables

\begin{tabular}{|c|c|c|c|}
\hline Status & Abbreviation for & Classification & Source \\
\hline MBEA & $\begin{array}{l}\text { Member state in } \\
\text { the euro area }\end{array}$ & $\begin{array}{l}\text { EU member state at stage three of the } \\
\text { Economic and Monetary Union, i.e., EU } \\
\text { member state in the euro area }\end{array}$ & $\begin{array}{l}\text { (European Central } \\
\text { Bank 2011) }\end{array}$ \\
\hline CCEA & $\begin{array}{l}\text { Candidate Country } \\
\text { for the euro area }\end{array}$ & $\begin{array}{l}\text { EU member state with derogation, i.e., a EU } \\
\text { member state (other than Sweden) that is } \\
\text { preparing to adopt the euro but has not } \\
\text { yet done so }\end{array}$ & $\begin{array}{l}\text { (European Central } \\
\text { Bank 2012, European } \\
\text { Union 2012) }\end{array}$ \\
\hline ACEU & $\begin{array}{l}\text { Acceding Country } \\
\text { for the EU }\end{array}$ & $\begin{array}{l}\text { Country that has signed the treaty of } \\
\text { accession }\end{array}$ & $\begin{array}{c}\text { (European } \\
\text { Commission 2012) }\end{array}$ \\
\hline CCEU & $\begin{array}{l}\text { Candidate Country } \\
\text { for the EU }\end{array}$ & $\begin{array}{l}\text { Applicant country for EU membership } \\
\text { that has been granted candidate country } \\
\text { status by the European Council }\end{array}$ & $\begin{array}{l}\text { (European } \\
\text { Commission 2012, } \\
\text { 2003, European } \\
\text { Council 2012) }\end{array}$ \\
\hline PCEU & $\begin{array}{l}\text { Potential Candidate } \\
\text { for the EU }\end{array}$ & $\begin{array}{l}\text { Central and Eastern European countries } \\
\text { that have signed Europe agreements; } \\
\text { Western Balkans countries involved in } \\
\text { the stabilization and association process } \\
\text { that are not yet candidate countries (six } \\
\text { Western Balkans countries were identified } \\
\text { as potential candidates during the } \\
\text { Thessaloniki European Council summit } \\
\text { in 2003; the European Council confirmed } \\
\text { a clear European perspective for Kosovo } \\
\text { in 2008); in 2009, Iceland applied to join } \\
\text { the EU }\end{array}$ & $\begin{array}{l}\text { (European } \\
\text { Commission 2012, } \\
\text { 2003, European } \\
\text { Council 2012) }\end{array}$ \\
\hline NO & No status & Other countries & \\
\hline
\end{tabular}

(Note) Many countries were granted candidate status at the European Council meetings held in December. As one should expect no effect for the respective year, our dummy variables generally display all changes in the status occurring during the months of November and December in the following year. Beyond that, we assign all the EU member states that adopted the euro in 1999 the CCEA status until 1998. A status dummy variable takes the value of one if and only if the country has that respective status and is zero otherwise. EU member states that have been granted exemption from participating in the third stage of the EMU (i.e., the United Kingdom (UK) and Denmark) and Sweden, which is de facto not willing to introduce the euro (European Central Bank 2012, European Union 2012), are not considered here. 
Although the notation and classification of a country's status are based on official specifications of the EU and the European Central Bank (ECB), they are not identical in the case of Sweden and potential candidates. Originally, the EU named countries involved in the stabilization and association process in the Western Balkans as potential candidates, which are not yet official candidate countries (European Commission 2012). We extend this term to all the countries implementing the pre-accession strategy of the EU according to the definition in Table 1. Sweden, which is officially an EU member state with derogation, is not considered here as Sweden is de facto not willing to introduce the euro. For example, it did not participate in the European Exchange Rate Mechanism (ERM and ERM II) in the relevant period.

\section{Descriptive statistics}

We first present some descriptive statistics. The WGIs' summary statistics for our sample are reported in Table 2. The means of the WGIs in our sample are above zero $(0.32-0.60)$ and the medians range from 0.35 to 0.90 . This indicates that most countries of our sample have better institutions than the world average. Interestingly, the median for each indicator is higher than its mean except for control of corruption. Hence, some countries have very high control of corruption, but many countries have a less-thaneffective control of corruption.

Table 2. Summary statistics of the WGIs

\begin{tabular}{|l|c|c|c|c|c|c|}
\hline & VaA & CoC & GE & PSNV & RoL & RQ \\
\hline Minimum value & -2.2097 & -1.4952 & -1.6757 & -2.2431 & -1.6924 & -2.1762 \\
\hline $1^{\text {st }}$ quartile & -0.1855 & -0.5226 & -0.3719 & -0.2970 & -0.4889 & -0.1083 \\
\hline Median & 0.8870 & 0.3591 & 0.7271 & 0.5025 & 0.7514 & 0.8978 \\
\hline Mean & 0.4951 & 0.4881 & 0.5964 & 0.3205 & 0.4783 & 0.6094 \\
\hline $3^{\text {rd }}$ quartile & 1.3137 & 1.4405 & 1.5760 & 1.0095 & 1.4304 & 1.3480 \\
\hline Maximum value & 1.8073 & 2.5856 & 2.2644 & 1.6681 & 1.9875 & 2.0766 \\
\hline Number of missing values & 4 & 14 & 19 & 22 & 14 & 20 \\
\hline
\end{tabular}

(Note) VaA: Voice and Accountability, CoC: Control of Corruption, GE: Government Effectiveness, PSNV: Political Stability and Absence of Violence, RoL: Rule of Law, RQ: Regulatory Quality. 
Table 3 displays the mean values of WGIs depending on the status variable. Mean values of the indicators increase from potential candidate countries to euro-area members. As expected, institutional development level is positively associated with steps toward EU membership and the introduction of the euro. This is in line with the conditionality principle, as discussed in Section II.A.

Table 3. Institutional development levels

\begin{tabular}{|c|c|c|c|c|c|c|}
\hline & VaA & CoC & GE & PSNV & RoL & RQ \\
\hline NO & 0.02 & 0.22 & 0.3 & 0.01 & 0.13 & 0.25 \\
\hline PCEU & 0.25 & -0.23 & -0.11 & -0.1 & -0.23 & 0.1 \\
\hline CCEU & 0.54 & 0.2 & 0.4 & 0.23 & 0.29 & 0.58 \\
\hline ACEU & 0.84 & 0.37 & 0.6 & 0.71 & 0.49 & 0.85 \\
\hline CCEA & 0.99 & 0.65 & 0.89 & 0.77 & 0.86 & 1.07 \\
\hline MBEA & 1.29 & 1.36 & 1.42 & 0.86 & 1.36 & 1.35 \\
\hline
\end{tabular}

(Notes) (i) VaA: Voice and Accountability, CoC: Control of Corruption, GE: Government Effectiveness, PSNV: Political Stability and Absence of Violence, RoL: Rule of Law, RQ: Regulatory Quality.

(ii) The abbreviations in left column are the statuses of European countries: NO: No status, PCEU: Potential Candidate for EU, CCEU: Candidate Country for EU, ACEU: Acceding Country for EU, CCEA: Candidate Country for Euro Area, MBEA: Member state in the Euro Area.

(iii) The table shows the mean values of the Worldwide Gevernance Indicatiors depending on the countries' status as defined in Table 1.

Table 4 displays the mean values of the first-differenced WGIs, that is, year-to-year changes in the WGIs depending on the status variable. The evidence is not conclusive, but countries in the early stages of EU accession exhibit a tendency of demonstrating greater improvements in the WGIs than euro-area members and EU member states preparing to adopt the euro. For almost all the indicators, (potential) candidate and acceding countries experienced improvement in their WGIs. For most indicators, the improvements are considerably higher than those experienced by the control group. In contrast, euro-area members experience deteriorations or no changes in their WGIs. The year-to-year changes are also quite small and partly negative for EU member states preparing to introduce the euro. 
Table 4. Impact on institutional development

\begin{tabular}{|c|c|c|c|c|c|c|}
\hline & VaA & CoC & GE & PSNV & RoL & RQ \\
\hline NO & 0.0095 & 0.0065 & 0.0104 & 0.009 & 0.0093 & 0.0119 \\
\hline PCEU & 0.0135 & 0.0317 & 0.0143 & -0.0233 & 0.0411 & 0.0293 \\
\hline CCEU & 0.0118 & 0.0047 & 0.0298 & 0.0188 & 0.0114 & 0.0242 \\
\hline ACEU & -0.0089 & 0.0941 & 0.0212 & 0.0627 & 0.0302 & -0.0029 \\
\hline CCEA & -0.0129 & 0.0053 & 0.0138 & -0.0107 & 0.0126 & 0 \\
\hline MBEA & -0.0054 & -0.0195 & -0.0188 & -0.0194 & -0.0053 & -0.0009 \\
\hline
\end{tabular}

(Notes) (i ) VaA: Voice and Accountability, CoC: Control of Corruption, GE: Government Effectiveness, PSNV: Political Stability and Absence of Violence, RoL: Rule of Law, RQ: Regulatory Quality.

(ii) The abbreviations in left column are the statuses of European countries: NO: No status, PCEU: Potential Candidate for EU, CCEU: Candidate Country for EU, ACEU: Acceding Country for EU, CCEA: Candidate Country for Euro Area, MBEA : Member state in the Euro Area.

(iii) The table shows the mean values of the year-to-year changes in the Worldwide Governance Indicators derending on the countries' status as defined in Table 1.

\section{Methodology}

\section{A. Econometric model}

Our empirical analysis aims to reveal institutional development induced by European integration. The hypotheses are as follows. The prospect of joining the EU inclines European countries to strengthen their institutions. Furthermore, EU member states preparing to introduce the euro have incentives to develop their institutions, but institutional development could be slower. ${ }^{9}$ As soon as a EU member state introduces the euro, institutional development grinds to a halt, or is even reversed, as there could be incentives to undo reforms. Of course, it is difficult to measure such incentives directly.

\footnotetext{
${ }^{9}$ In principle, one could use an $F$-test to determine whether the marginal effect of, for example, candidate status is higher than that of being a EU member state. This could point to whether institutional development is faster in candidate countries than in member states preparing for the introduction of the euro. However, in practice, the standard errors are too high to establish reasonable differences when both marginal effects are positive. Indeed, we will show that there is no significant marginal effect on institutional development from preparing to introduce the euro.
} 
In fact, we can only capture actual outcomes, that is, the values of the indicators for institutional development.

It must be pointed out that a country's status may affect its institutional development after a time lag rather than instantaneously since it usually takes some time to implement institutional reforms. Beyond that, one can suppose a level effect for institutional development. Leaving other variables constant, a country that is highly developed institutionally will probably face more difficulties in further developing its institutions at the same pace than a less institutionally developed country would. Moreover, the marginal effect of country's status may depend on the WGIs' level. Therefore, we introduce interaction terms between the status variables and lagged-level WGIs. ${ }^{10}$ This also allows for different slopes for the level effect of the WGIs depending on the status. ${ }^{1}$

Institutional development and growth theory posits the following relationships between institutional development and time-varying control variables. Institutional development depends positively on GDP per capita and a country's level of openness. ${ }^{12}$ The control variables probably affect the institutional development with a time lag. Hence, we introduce the first lags of the control variables to the estimation equation. Finally, one can also test for country and time effects.

The issue of the potential endogeneity of regressors is highly relevant to our analysis. If one regressor is correlated with the error term, the least-squares estimates of coefficients are inconsistent. This is called the simultaneous equation bias (Baltagi 2008). We hypothesize the influence of a European country's status on a change in the WGIs. However, the reverse is also likely to be true. As (potential) candidate and acceding countries improve their institutions, they are rewarded with higher status. This corresponds to the conditionality principle discussed in Section II.A that a country's status toward accession is linked to its institutional development. It is reasonable to assume a delay of the reward for at least one period as evaluation by the Commission and the political decision process take some time. Hence, the status variable in Equation (1) is probably weakly exogenous or predetermined.

As for the status variable, reverse causality may also apply to the control variables

\footnotetext{
${ }^{10}$ The hypothesis to be tested is conditional in nature. For example, being a potential candidate country is associated with an institutional improvement if the institutional development level is low but not if the institutional development level is high. More precisely, the lower the previous years' WGIs, the greater is the improvement in the WGIs.

${ }^{11}$ Indeed, both statements (effect of the status depends on the previous period WGIs; level effect of previous periods' WGIs depends on the status) are logically symmetric. An interaction model cannot distinguish which variable (status or WGI) is the conditioning one (Kam and Franzese 2005, Brambor et al. 2006). Both statements are interesting on their own, and we proceed to analyze them both.

${ }^{12}$ We also tested Foreign Direct Investments (FDI) as control variable. The intuition is that FDI inflows can induce a transfer of best practices and competition in a country. FDI turned out to be insignificant in every specification, so we dropped this control variable.
} 
of GDP per capita and openness. The growth and development literature, which tries to identify the effect of good institutions on economic development, struggles with analyzing the interrelationship between these variables. Hence, the minimum requirement is to include lagged values of weakly exogenous or predetermined variables in the regression equation.

According to our considerations, we form the following estimation equation:

$$
\begin{array}{r}
W G I_{i, t}=\beta_{0}+\beta_{1} W G I_{i, t-1}+\text { Status }_{i, t-1}^{\prime} \boldsymbol{\beta}_{2}+W G I_{i, t-1} \text { Status }_{i, t-1}^{\prime} \boldsymbol{\beta}_{3} \\
+\beta_{4} G D P_{i, t-1}+\beta_{5} \text { Trade }_{i, t-1}+\alpha_{i}+\gamma_{t}+\varepsilon_{i, t}
\end{array}
$$

$W G I_{t-1}$ is the lagged dependent variable, and its coefficient $\beta_{1}$ indicates the persistence of the WGI. The variable Status $_{i, t-1}$ is not continuous but a column vector of the status

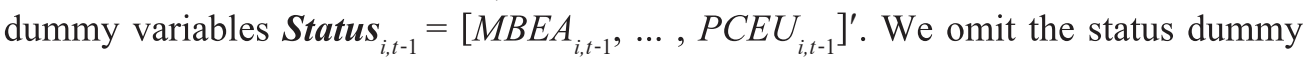
variable $N O$, which indicates the base group, to avoid the dummy variable trap. $\boldsymbol{\beta}_{2}$ and $\boldsymbol{\beta}_{3}$ are the corresponding vectors of coefficients, $\alpha_{i}$ is the fixed effect, $\gamma_{t}$ is the time effect, and $\varepsilon_{i, t}$ is the disturbance term. GDP $P_{i, t-1}$ and Trade ${ }_{i, t-1}$ are the control variables GDP per capita in US dollars and trade as a percentage of the GDP. Trade is defined as imports plus exports. ${ }^{13}$ All the control variables are in logarithms. ${ }^{14}$

The model can be considered for the level of or increase in the WGIs. Rearranging Equation (1) yields

$$
\begin{array}{r}
\Delta W G I_{i, t}=\beta_{0}+\left(\beta_{1}-1\right) W G I_{i, t-1}+\text { Status }_{i, t-1}^{\prime} \boldsymbol{\beta}_{2}+\text { WGI }_{i, t-1} \text { Status }_{i, t-1}^{\prime} \boldsymbol{\beta}_{3} \\
+\beta_{4} \operatorname{GDP}_{i, t-1}+\beta_{5} \text { Trade }_{i, t-1}+\alpha_{i}+\gamma_{t}+\varepsilon_{i, t}
\end{array}
$$

This rearrangement clarifies that we are interested in explaining institutional development, that is, expected changes in the WGIs. All the coefficients are identical, but the coefficient of the lagged dependent variable becomes less intuitive to interpret. Therefore, we estimate Equation (1) throughout the entire analysis.

To illustrate the interpretation of the dummy variables' coefficients and their interaction terms with the WGIs, we present the conditional expectations of Equation (1).

\footnotetext{
${ }^{13}$ Data for GDP per capita in US dollars and trade in percentage of GDP are from the World Development Indicators (World Bank 2012).

${ }^{14}$ It is not necessary to include time-invariant control variables in Equation (1). Once we remove the fixed effects, all time-invariant determinants, which could affect institutional development and are correlated with the other regressors, are excluded from the estimation equation.
} 
For the base group, the conditional expectation is

$$
\begin{array}{r}
E\left(W_{i, t} \mid\left[\operatorname{PCEU}_{i, t-1}, \ldots, \operatorname{MBEA}_{i, t-1}\right]^{\prime}=0, W G I_{i, t-1}, G D P_{i, t-1}, \operatorname{Trade}_{i, t-1}, \alpha_{i}, \gamma_{t}\right) \\
=\beta_{0}+\beta_{1} W G I_{i, t-1}+\beta_{4} G D P_{i, t-1}+\beta_{5} \operatorname{Trade}_{i, t-1}+\alpha_{i}+\gamma_{t}
\end{array}
$$

The WGIs are supposed to be state-dependent. Hence, the coefficient $\beta_{1}$ is between zero and one. For potential candidate countries, the conditional expectation of Equation (1) is

$$
\begin{aligned}
& E\left(W G I_{i, t} \mid P C E U_{i, t-1}=1,\left[C C E U_{i, t-1}, \ldots, M B E A_{i, t-1}\right]^{\prime}=0, W G I_{i, t-1}, G D P_{i, t-1}, \text { Trade }_{i, t-1}, \alpha_{i}, \gamma_{t}\right) \\
& =\left(\beta_{0}+\beta_{2}^{\text {PCEU }}\right)+\left(\beta_{1}+\beta_{3}^{\text {PCEU }}\right) W G I_{i, t-1}+\beta_{4} G D P_{i, t-1}+\beta_{5} \text { Trade }_{i, t-1}+\alpha_{i}+\gamma_{t}
\end{aligned}
$$

As we suppose a positive intercept shift and a reduction in persistence of the WGIs (slope shift), $\beta_{2}^{P C E U}$ should be positive and $\beta_{3}^{P C E U}$ negative, respectively. The derivations of the conditional expectations for the other status dummy variables are analogous.

In interaction models, interpreting the coefficients deserves some attention and rigor. The coefficient of a constitutive term, which is one element that constitutes an interaction term (e.g., $\beta_{1}$ or $\beta_{2}$ ), must not be interpreted as the marginal or average effect of a change in the independent variable upon the dependent variable. ${ }^{15}$ Moreover, the standard errors of interest are not those of $\beta_{2}$ or $\beta_{3}$ but of $\frac{\partial W G I_{t}}{\partial \text { Status }_{t-1}}=\beta_{2}+\beta_{3} W G I_{t-1}$. Hence, the standard error of interest can be calculated as ${ }^{16}$

$$
\hat{\sigma}_{\frac{\partial W G I_{t}}{\partial \text { Status }_{t-1}}}=\sqrt{\operatorname{var}\left(\hat{\beta}_{2}\right)+W G I_{t-1}^{2} \operatorname{var}\left(\hat{\beta}_{3}\right)+2 W G I_{t-1} \operatorname{cov}\left(\hat{\beta}_{2} \hat{\beta}_{3}\right)}
$$

We calculated the marginal effects, standard errors, and confidence intervals for all status variables depending on the previous year's governance indicator when presenting the baseline estimation results in Section $\mathrm{V}$.

\footnotetext{
${ }^{15}$ The coefficient $\beta_{2}$ only captures the effect of Status $s_{t-1}$ on $W G I_{t}$ when $W G I_{t-1}$ is zero. For example, a country with world average quality in institutions (governance indicator is zero) will experience an increase in its institutional quality by $\beta_{2}$ if it was a potential EU candidate country in the last year.

${ }^{16}$ Brambor et al. (2006) provide a valuable discussion of what to do and not to do with interaction models. In interaction models of the type $Y=\beta_{0}+\beta_{1} X+\beta_{2} Z+\beta_{3} X Z+\varepsilon$, where $Z$ is the conditioning variable, the standard error of the marginal effect of $X$ on $Y$ is (Brambor et al. 2006)

$$
\hat{\sigma}_{\partial \mathrm{Y} / \partial \mathrm{X}}=\sqrt{\operatorname{var}\left(\hat{\beta}_{1}\right)+Z^{2} \operatorname{var}\left(\hat{\beta}_{3}\right)+2 Z \operatorname{cov}\left(\hat{\beta}_{1} \hat{\beta}_{3}\right)} .
$$
}




\section{B. Estimation method}

It is very difficult to select an appropriate estimator for a dynamic panel data model where the number of observed countries is not that large relative to the observation period (so-called macroeconomic panel data), because all existing estimators have drawbacks. ${ }^{17}$ The fixed-effects estimator is generally biased in dynamic models, a situation known as the Nickell bias (Nickell 1981). However, as $T$ increases, the fixedeffects estimator becomes consistent (Baltagi 2008). ${ }^{18}$ Our sample period is sufficiently large so that the bias should not be large in our estimation. Alternative estimators that are usually used in the dynamic panel data context are the generalized method of moments (GMM) procedures, such as the Arellano-Bond estimator, the Arellano-Bover estimator, and the Blundell-Bond estimator; yet, they are particularly suited to short panels with $T$ fixed and $N \rightarrow \infty$ (Cameron and Trivedi 2007). To verify that our results are robust even when considering the limitations of the fixed-effects estimator in dynamic panel data models and in terms of the potential problems described earlier, we apply the BlundellBond system GMM estimator in Section V.B.

Applying the system GMM estimator, the second lag up to the first observation of the untransformed variable can be used as instruments for endogenous variables. For predetermined variables, the first lag is additionally valid. For strict exogenous variables, all observations are valid instruments. Additionally, lagged differences are used as instruments for the equations in levels. However, the instrument count becomes very large, which may lead to poor small-sample properties of the estimator and hypothesis tests. ${ }^{19}$ This problem also arises if the time dimension $T$ becomes large relative to the cross-section dimension $N$ since the instrument count is quadratic in $T$. Although methods have been developed to reduce the number of instruments, ${ }^{20}$ it may still be too large in typical macroeconomic settings where $N$ is relatively small (e.g., 30) (Breitung

\footnotetext{
${ }^{17}$ In his review, Breitung (2015) concludes that the econometric analysis of macroeconomic panel data is still in its infancy.

${ }^{18}$ As the Nickell bias, the bias of weakly exogenous or predetermined regressors is also inversely related to the size of the time dimension (Breitung 2015). Bias size decreases as the time dimension increases.

${ }^{19}$ As a result, the GMM estimators suffer from the problem of instrument proliferation leading to small-sample bias and unreliable inference (Breitung 2015). However, there is no formal test or accepted rule of thumb regarding the number of instruments (Roodman 2009).

${ }^{20}$ Methods for reducing the number of instruments in a panel GMM have been proposed by Breitung (1994), Judson and Owen (1999), and Roodman (2009), among others. However, they come at the expense of efficiency. The most intuitive method is to restrict the number of lags to be used as instruments (Judson and Owen 1999, Roodman 2009). The second method is to collapse the instruments (Roodman 2009).
} 
1994). ${ }^{21}$ Although we restrict the lags and collapse the instruments as far as possible, the instrument count remains quite substantial (but less than the number of countries). Moreover, the use of biannual data, which reduces the number of observation periods from $T=17$ to $T=9$, limits the number of instruments but increases the finite sample bias of the system GMM estimator. The intuition behind this approach is that less information is available to estimate the true parameter. Therefore, the estimates with system GMM as well as the estimates with the two-way within estimator should be handled with care.

\section{Results}

\section{A. Baseline results}

Now, we turn to the estimates of Equation (1). Table 5 shows the results of six regressions; in each regression, one governance indicator is the dependent variable. The regressions are estimated by two-way within OLS, which accounts for time and fixed effects. Panel robust standard errors allowing for heteroscedasticity across countries and serial correlation are reported. 22

\footnotetext{
${ }^{21}$ Alternative estimators have been developed that are asymptotically efficient as $T$ tends to infinity. These are the bias-adjustment and maximum likelihood type estimators. Corrected within-group estimators perform best in dynamic panel data models with moderate to large $T$. Maximum likelihood estimators may be superior if $T$ is small and the autoregressive coefficient is close to unity. However, the attractive features of bias-adjustment and maximum likelihood-type estimators come at the expense of more restrictive model assumptions (Breitung 2015). Most relevant in our context is the restrictive assumption of strictly exogenous regressors. Hence, there is not much to gain in applying these alternative estimators with respect to our coefficients of interest. Taking into account the limited gain in applying these estimators, we favor the approach of estimating Equation (1) by two-way within OLS and system GMM to check the robustness of our results.

${ }^{22}$ Our results were obtained using R 2.15.2 with the packages plm 1.3-1, lmtest 0.9-32, and car 2.0-19 (R Core Team 2012, Croissant and Millo 2008, Zeileis and Hothorn 2002, Fox and Weisberg 2011).
} 
Table 5. Least-squares estimates

(with annual data)

\begin{tabular}{|c|c|c|c|c|c|c|}
\hline \multirow{2}{*}{ Independent variables } & \multicolumn{6}{|c|}{ Dependent variables } \\
\hline & $\mathbf{V a A}$ & $\mathrm{CoC}$ & GE & PSNV & RoL & RQ \\
\hline $\operatorname{lag}(W G I)$ & $\begin{array}{l}0.8009^{* * *} \\
(0.0198)\end{array}$ & $\begin{array}{l}0.7784^{* * *} \\
(0.0224)\end{array}$ & $\begin{array}{l}0.7963^{* * *} \\
(0.0360)\end{array}$ & $\begin{array}{l}0.7030^{* * *} \\
(0.0337)\end{array}$ & $\begin{array}{l}0.8218^{* * *} \\
(0.0299)\end{array}$ & $\begin{array}{l}0.7819^{* * *} \\
(0.0319)\end{array}$ \\
\hline $\operatorname{lag}(P C E U)$ & $\begin{array}{l}-0.0233 \\
(0.0265)\end{array}$ & $\begin{array}{c}0.0146 \\
(0.0224)\end{array}$ & $\begin{array}{c}0.0268 \\
(0.0257)\end{array}$ & $\begin{array}{c}0.0288 \\
(0.0334)\end{array}$ & $\begin{array}{c}0.0347 \\
(0.0245)\end{array}$ & $\begin{array}{l}0.0545^{* * *} \\
(0.0183)\end{array}$ \\
\hline $\operatorname{lag}(C C E U)$ & $\begin{array}{c}0.0630 \\
(0.0542)\end{array}$ & $\begin{array}{c}0.0416 \\
(0.0449)\end{array}$ & $\begin{array}{l}0.1061^{* * *} \\
(0.0269)\end{array}$ & $\begin{array}{l}0.0762^{*} \\
(0.0408)\end{array}$ & $\begin{array}{c}0.0383 \\
(0.0263)\end{array}$ & $\begin{array}{c}0.0455 \\
(0.0414)\end{array}$ \\
\hline $\operatorname{lag}(A C E U)$ & $\begin{array}{l}0.1688^{* *} \\
(0.0801)\end{array}$ & $\begin{array}{c}0.0379 \\
(0.0820)\end{array}$ & $\begin{array}{c}0.0558 \\
(0.0504)\end{array}$ & $\begin{array}{c}0.0396 \\
(0.0809)\end{array}$ & $\begin{array}{l}0.0763^{*} \\
(0.0411)\end{array}$ & $\begin{array}{l}0.2065 \\
(0.0751)\end{array}$ \\
\hline $\operatorname{lag}(C C E A)$ & $\begin{array}{c}0.0217 \\
(0.0511)\end{array}$ & $\begin{array}{c}0.0142 \\
(0.0499)\end{array}$ & $\begin{array}{c}0.0544 \\
(0.0408)\end{array}$ & $\begin{array}{c}0.0549 \\
(0.0553)\end{array}$ & $\begin{array}{c}0.0524 \\
(0.0386)\end{array}$ & $\begin{array}{c}0.0483 \\
(0.0614)\end{array}$ \\
\hline $\operatorname{lag}(M B E A)$ & $\begin{array}{c}0.0098 \\
(0.0740)\end{array}$ & $\begin{array}{l}-0.1302^{* *} \\
(0.0618)\end{array}$ & $\begin{array}{c}0.0286 \\
(0.0435)\end{array}$ & $\begin{array}{l}-0.0844 \\
(0.0728)\end{array}$ & $\begin{array}{c}0.0329 \\
(0.0341)\end{array}$ & $\begin{array}{c}0.0675 \\
(0.0645)\end{array}$ \\
\hline lag (GDP per capita US) & $\begin{array}{l}-0.0353 \\
(0.0317)\end{array}$ & $\begin{array}{c}0.0415 \\
(0.0378)\end{array}$ & $\begin{array}{l}0.1253^{* * *} \\
(0.0408)\end{array}$ & $\begin{array}{l}0.1929^{* * *} \\
(0.0598)\end{array}$ & $\begin{array}{l}0.0929^{* *} \\
(0.0379)\end{array}$ & $\begin{array}{l}0.1284^{* *} \\
(0.0441)\end{array}$ \\
\hline $\operatorname{lag}($ Trade $)$ & $\begin{array}{c}0.0194 \\
(0.0253)\end{array}$ & $\begin{array}{c}0.0363 \\
(0.0326)\end{array}$ & $\begin{array}{c}0.0638 \\
(0.0422)\end{array}$ & $\begin{array}{l}0.1113{ }^{*} \\
(0.0668)\end{array}$ & $\begin{array}{l}0.0648^{*} \\
(0.0279)\end{array}$ & $\begin{array}{l}0.0752^{*} \\
(0.0335)\end{array}$ \\
\hline $\operatorname{lag}(W G I)^{*} \operatorname{lag}(P C E U)$ & $\begin{array}{c}0.0052 \\
(0.0446)\end{array}$ & $\begin{array}{l}-0.0511^{*} \\
(0.0296)\end{array}$ & $\begin{array}{l}-0.0760 \\
(0.0282)\end{array}$ & $\begin{array}{l}-0.0398 \\
(0.0328)\end{array}$ & $\begin{array}{l}-0.0340 \\
(0.0193)\end{array}$ & $\begin{array}{l}-0.0608 \\
(0.0400)\end{array}$ \\
\hline $\operatorname{lag}(W G I) * \operatorname{lag}(C C E U)$ & $\begin{array}{l}-0.1005^{*} \\
(0.0525)\end{array}$ & $\begin{array}{l}-0.1110 \\
(0.0255)\end{array}$ & $\begin{array}{l}-0.1355^{* * *} \\
(0.0286)\end{array}$ & $\begin{array}{c}-0.1255^{* * * *} \\
(0.0358)\end{array}$ & $\begin{array}{c}-0.0701^{* * * *} \\
(0.0196)\end{array}$ & $\begin{array}{l}-0.0534 \\
(0.0527)\end{array}$ \\
\hline $\operatorname{lag}(W G I) * \operatorname{lag}(A C E U)$ & $\begin{array}{l}-0.2427^{* * *} \\
(0.0830)\end{array}$ & $\begin{array}{l}-0.0965 \\
(0.1180)\end{array}$ & $\begin{array}{l}-0.1313^{* * *} \\
(0.0453)\end{array}$ & $\begin{array}{l}-0.2096 \\
(0.0847)\end{array}$ & $\begin{array}{l}-0.1695^{* * *} \\
(0.0435)\end{array}$ & $\begin{array}{l}-0.2130 \\
(0.0719)\end{array}$ \\
\hline $\operatorname{lag}(W G I)^{*} \operatorname{lag}(C C E A)$ & $\begin{array}{l}-0.0571 \\
(0.0475)\end{array}$ & $\begin{array}{l}-0.0284 \\
(0.0320)\end{array}$ & $\begin{array}{l}-0.0155 \\
(0.0300)\end{array}$ & $\begin{array}{l}-0.0860 \\
(0.0504)\end{array}$ & $\begin{array}{l}-0.0461 \\
(0.0250)\end{array}$ & $\begin{array}{l}-0.0521 \\
(0.0579)\end{array}$ \\
\hline $\operatorname{lag}(W G I)^{*} \operatorname{lag}(M B E A)$ & $\begin{array}{l}-0.0575 \\
(0.0654)\end{array}$ & $\begin{array}{c}0.0341 \\
(0.0430)\end{array}$ & $\begin{array}{l}-0.0444 \\
(0.0334)\end{array}$ & $\begin{array}{l}-0.0351 \\
(0.0539)\end{array}$ & $\begin{array}{l}-0.0504^{*} \\
(0.0261)\end{array}$ & $\begin{array}{l}-0.0702 \\
(0.0488)\end{array}$ \\
\hline$R^{2}$ & 0.7318 & 0.7094 & 0.7265 & 0.5898 & 0.7831 & 0.6934 \\
\hline Adjusted $R^{2}$ & 0.6614 & 0.6409 & 0.6562 & 0.5326 & 0.7075 & 0.6262 \\
\hline Number of observations & 873 & 870 & 868 & 865 & 870 & 867 \\
\hline
\end{tabular}

(Notes) (i) The columns display the results of six regressions; in each regression, one Worldwide Governance Indicator (WGI) is the dependent variable. Additionally its lag is used as an independent variable. 
(ii) $*, * *$ and $* * *$ indicate significance at the $10 \%, 5 \%$, and $1 \%$ level, respectively; lag() denotes lagged one period; sample: 1996 2012, 56 countries, unbalanced panel because of data availability; twoway within OLS estimator; panel robust standard errors are reported in parentheses.

(iii) VaA: Voice and Accountability, CoC: Control of Corruption, GE: Government Effectiveness, PSNV: Political Stability and Absence of Violence, RoL: Rule of Law, RQ: Regulatory Quality.

(iv) The abbreviations are the statuses of European countries, PCEU: Potential Candidate for EU, CCEU: Candidate Country for EU, ACEU: Acceding Country for EU, CCEA: Candidate Country for Euro Area, MBEA: Member state in the Euro Area.

We first discuss whether a country's status has any effect on the WGIs, which corresponds to the null hypothesis $\beta_{2}=\beta_{3}=0$. The $F$-tests for this null hypothesis are presented in Table 6 for each regression and status variable. It can be concluded that potential candidate countries experience a significant effect on government effectiveness and regulatory quality at the $5 \%$ level and additionally on control of corruption and rule of law at the $10 \%$ level. Being a candidate or an acceding country significantly influences almost all the WGIs. On the other hand, being an EU member state preparing to introduce the euro or an euro-area country does not influence institutional development. The only exception is the effect of euro-area membership on control of corruption, which is significant at the $10 \%$ level. 
Table 6. $F$-tests on the baseline results

\begin{tabular}{|l|c|c|c|c|c|c|}
\hline \multirow{2}{*}{ Null hypothesis } & \multicolumn{5}{|c|}{$P$-values of the F-tests on the six regressions } \\
\cline { 2 - 7 } & $\mathbf{V a A}$ & $\mathbf{C o C}$ & $\mathbf{G E}$ & $\mathbf{P S N V}$ & $\mathbf{R o L}$ & RQ \\
\hline $\begin{array}{l}\operatorname{lag}(P C E U)=0, \\
\operatorname{lag}(W G I)^{*} \operatorname{lag}(P C E U)=0\end{array}$ & 0.5958 & 0.093 & 0.0218 & 0.2092 & 0.0665 & 0.0003 \\
\hline $\begin{array}{l}\operatorname{lag}(C C E U)=0, \\
\operatorname{lag}(W G I)^{*} \operatorname{lag}(C C E U)=0\end{array}$ & 0.1409 & 0 & 0 & 0.0008 & 0.0016 & 0.5176 \\
\hline $\begin{array}{l}\operatorname{lag}(A C E U)=0, \\
\operatorname{lag}(W G I)^{*} \operatorname{lag}(A C E U)=0\end{array}$ & 0.0085 & 0.7156 & 0.0126 & 0.012 & 0.0005 & 0.0108 \\
\hline $\begin{array}{l}\operatorname{lag}(C C E A)=0, \\
\operatorname{lag}(W G I)^{*} \operatorname{lag}(C C E A)=0\end{array}$ & 0.4127 & 0.6588 & 0.4117 & 0.2251 & 0.1583 & 0.6583 \\
\hline $\begin{array}{l}\operatorname{lag}(M B E A)=0, \\
\operatorname{lag}(W G I)^{*} \operatorname{lag}(M B E A)=0\end{array}$ & 0.3657 & 0.0848 & 0.4132 & 0.1477 & 0.1443 & 0.3561 \\
\hline
\end{tabular}

(Notes) (i) The null hypothesis is that a country's status toward the European integration process has no effect on the respective WGI; i.e. that the coefficients of the status variable and their interaction term with the WGI are both zero.

(ii) Estimates of panel robust covariance matrixes, allowing for heteroscedasticity across countries and serial correlation, are provided.

(iii) VaA: Voice and Accountability, CoC: Control of Corruption, GE: Government Effectiveness, PSNV: Political Stability and Absence of Violence, RoL: Rule of Law, RQ: Regulatory Quality.

(iv) The abbreviations are the statuses of European countries, PCEU: Potential Candidate for EU, CCEU: Candidate Country for EU, ACEU: Acceding Country for EU, CCEA: Candidate Country for Euro Area, MBEA : Member state in the Euro Area.

We proceed by interpreting the model in two ways: first, when Status $_{t-1}$ is the conditioning variable and second, when $W G I_{t-1}$ is the conditioning variable. The first case allows for different intercepts and slopes for the level effect of the WGIs depending on status. Table 5 shows that the WGIs are state-dependent for all six dimensions. The coefficients of the lagged dependent variables are within the $0.70-0.82$ range and highly significant. The coefficients of the status dummy variables are mostly positive, with a few exceptions, which corresponds to an upward intercept shift of the regression line (we call this the direct effect). The prospect of joining the EU has significant direct effects on voice and accountability, government effectiveness, and regulatory quality. Being a candidate country speeds up the development of government effectiveness, and the accession status contributes positively to voice and accountability. Potential candidate 
countries and acceding countries experience an improvement in regulatory quality. There are no significant direct effects on EU member states preparing for the introduction of the euro. For control of corruption, the coefficient of member state of euro area is negative and significant at the $5 \%$ level. Thus, there seems to be a direct negative effect of being a euro-area country on control of corruption.

Candidate and acceding countries experience a significant reduction in institutional persistence for almost all the WGIs (which we call the indirect effect of the status). The coefficients of the interaction terms are negative and significant. The institutional persistence in government effectiveness also decreases in potential candidate countries (for control of corruption and rule of law, the significance is at the $10 \%$ level). In contrast, both EU member states preparing to introduce the euro and euro-area countries barely experience a significant influence on their institutional development path. Institutional persistence is lowest for candidate and acceding countries. ${ }^{23}$ In Table 5, we see that the control variable GDP per capita is positive and significant for most indicators, as expected. Trade is positive and significant for rule of law and regulatory quality at the 5\% level and for political stability and absence of violence at the $10 \%$ level.

Now, we evaluate if the marginal effect of status may depend on WGI levels. Figure 1 through Figure 6 illustrate how the marginal effect of Status ${ }_{t-1}$ changes across a country's level in institutional development. The solid line shows the marginal effect of Status ${ }_{t-1}$ depending on $W G I_{t-1}$, and the dashed lines are the confidence intervals. For example, Figure 3 indicates that the effect of becoming a potential candidate country is statistically significant at conventional levels for countries at relatively low levels of institutional development (government effectiveness below approximately -0.4). In contrast, there is no statistically significant effect for highly institutionally developed countries. ${ }^{24}$

Over all WGIs, a rather homogenous picture emerges. Potential candidate countries improve significantly in four dimensions of governance when the institutional development level is low (below global average). For slightly other WGIs, the same finding can be affirmed for candidate countries, but the marginal effect is twice as large. For most WGIs, the effect is even greater when a country is an EU acceding country. However, the standard errors are also considerably larger. Moreover, (potential)

\footnotetext{
${ }^{23}$ To calculate the marginal effects of $W G I_{t-1}$ on $W G I_{t}$ depending on the status, one has to add up $\beta_{1}$ and $\beta_{3}$.

${ }^{24}$ It is useful to complement the insights of Table 5 and Figure 3 with a quantitative assessment of the impact of being a potential candidate country on government effectiveness. Let us assume that Albania, whose government effectiveness indicator score was -0.80 in 1996, would have been a potential candidate in 1996. This would have raised Albania's indicator score by 0.09 in 1997, holding other variables constant. Once the government effectiveness score exceeds -0.4 , the effect of being a potential candidate on government effectiveness is no longer statistically significant different from zero.
} 
candidates and acceding countries with relatively low levels of institutional development benefit most from the EU accession process. In contrast, highly institutionally developed (potential) candidate and acceding countries do not experience any significant improvement to their institutions because of EU accession.

To better judge the substantive implication of the results, we provide boxplots of the sample for all WGIs (Figure 7). These reveal the approximate percentage of the sample that falls within the region of significance. Around half of the observations of potential candidate countries and control group are located within the region where marginal effects of PCEU, CCEU, and ACEU are significant. Moreover, roughly 25\% of the observations for candidate countries lie within this region. Hence, it can be concluded that being a (potential) candidate or an acceding country has a positive effect on institutional development.

There are no significant effects on institutional development for EU member states preparing to introduce the euro or euro-area members, except for effects on control of corruption. Euro-area members experience a significant deterioration in control corruption if this indicator score lies between -0.3 to 1.0 in the previous year; this observation is highly relevant for policy. For euro-area members, around $25 \%$ of observations fall within this range. In 2012, the control of corruption score was below one for seven members of the euro area ${ }^{25}$ and for $75 \%$ of the EU member states that have not yet introduced the euro. In the same year, all new member states had sub optimal control of corruption. They are all members of the EMU with derogation, and some of them recently adopted the euro.

To conclude, there is evidence that (potential) candidate and acceding countries perform better than the control group. In particular, prospective EU membership induces institutional development in laggard countries and reduces the persistance of institutional development. There are virtually no differences in the performance of member states preparing to adopt the euro, euro-area members, and the control group. The only exception is the negative impact of being a euro-area member on control of corruption.

${ }^{25}$ These countries are Greece, Italy, Malta, Portugal, Slovak Republic, Slovenia, and Estonia. 
Figure 1. Marginal effect of Status $_{t-1}$ on VaA

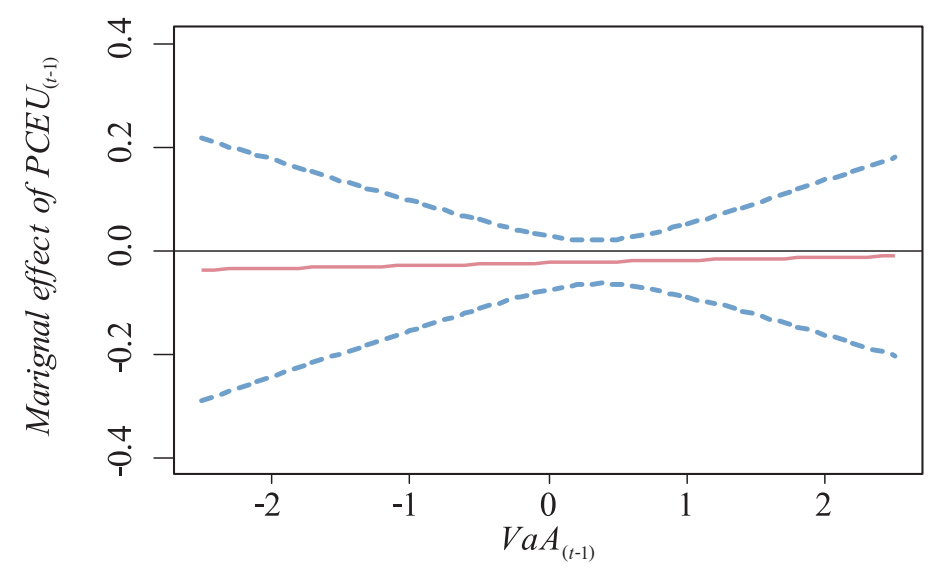

- 95\% Confidence interval

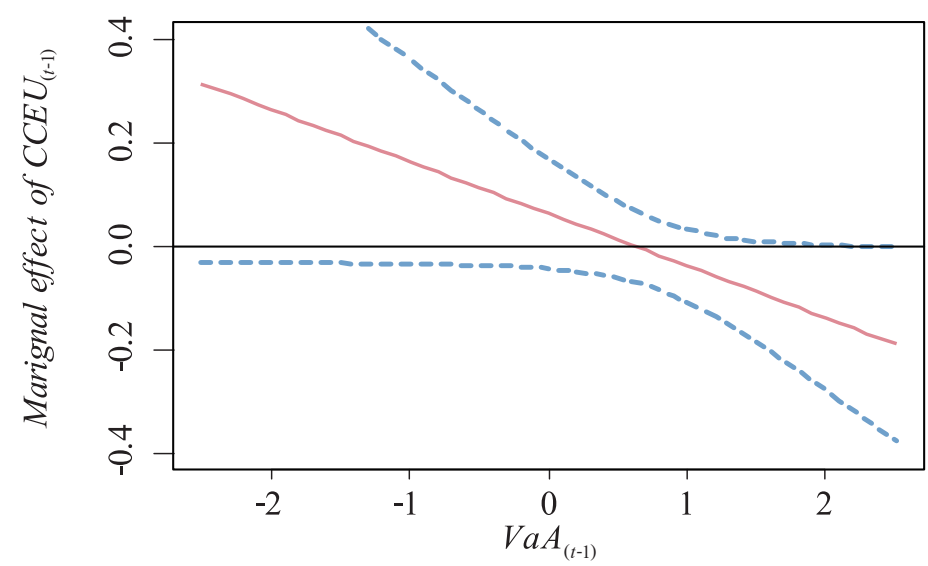

- - - 95\% Confidence interval

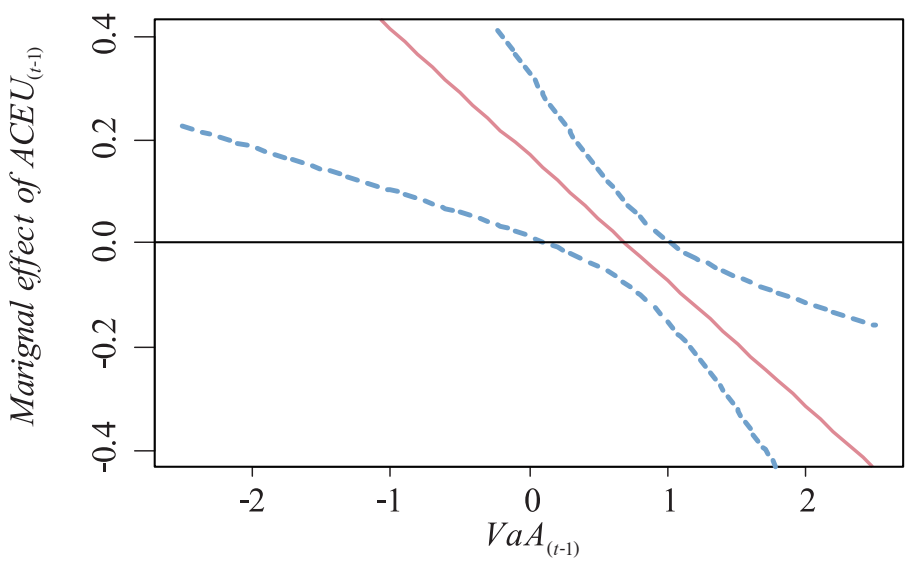

- - - 95\% Confidence interval 


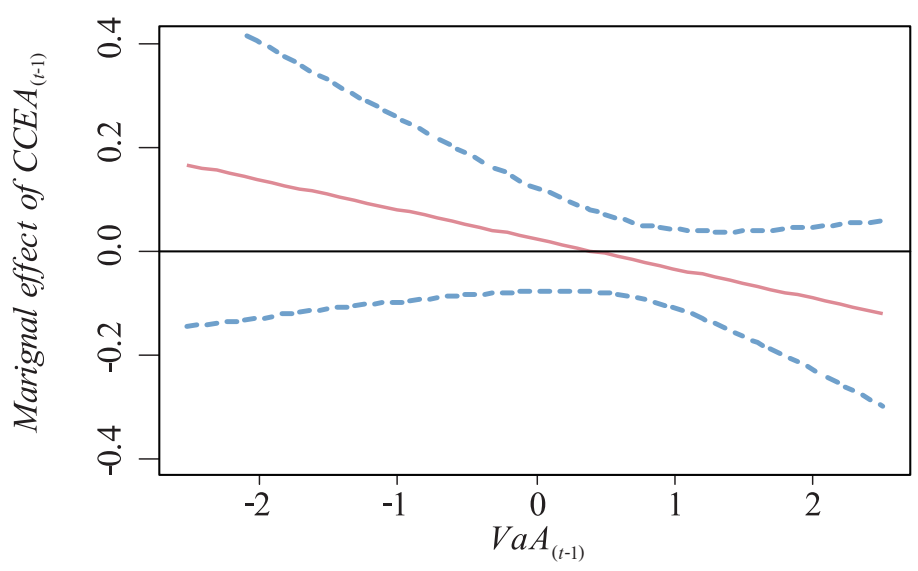

$----95 \%$ Confidence interval

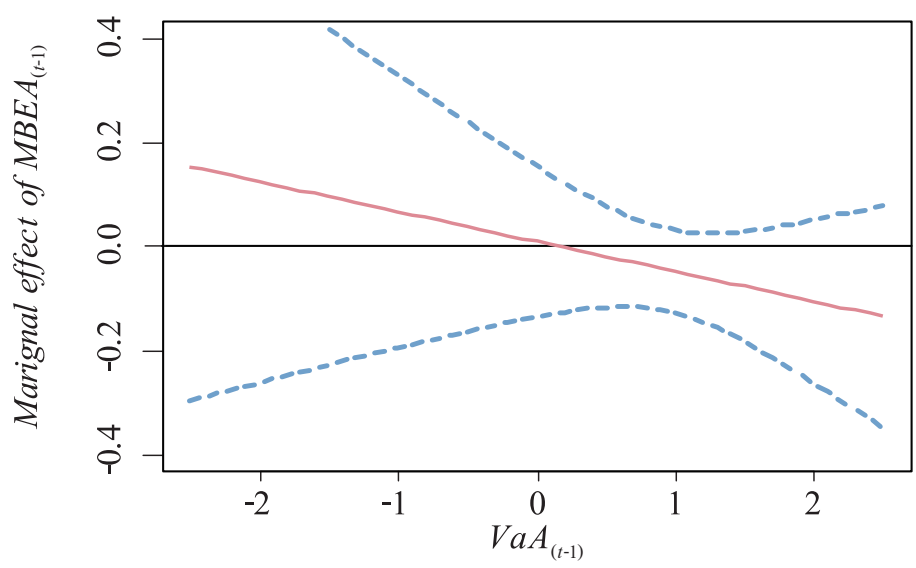

$---95 \%$ Confidence interval

(Note) VaA: Voice and Accountability; MBEA: Member state in the Euro Area; CCEA: Candidate Country for the Euro Area; ACEU: Acceding Country for the EU; CCEU: Candidate country for the EU; PCEU: Potential Candidate for the EU. 
Figure 2. Marginal effect of Status ${ }_{t-1}$ on CoC

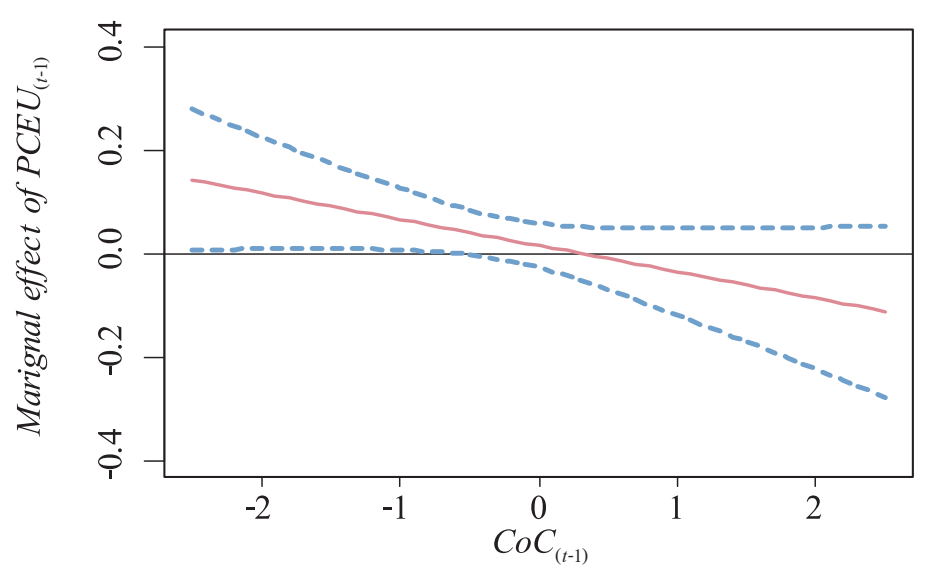

- - - - 95\% Confidence interval

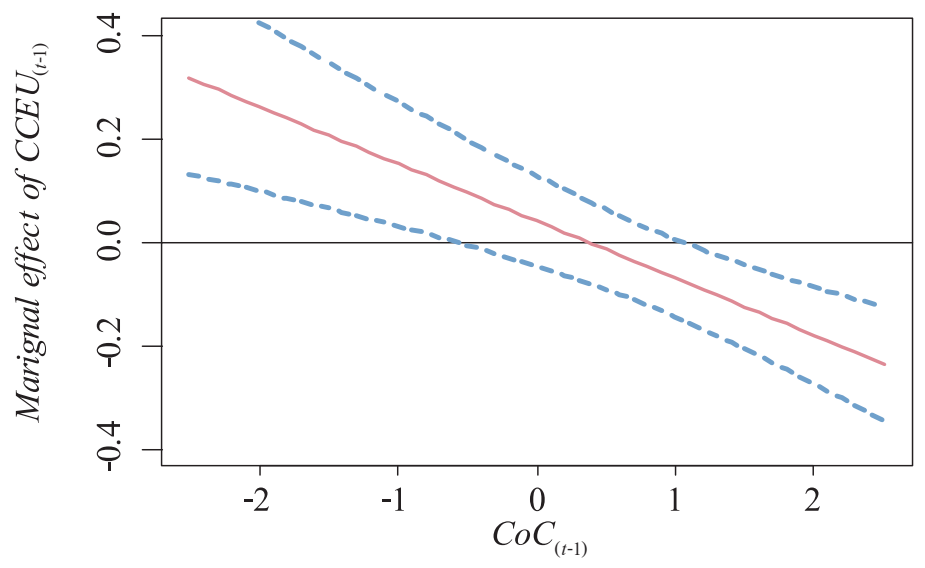

95\% Confidence interval

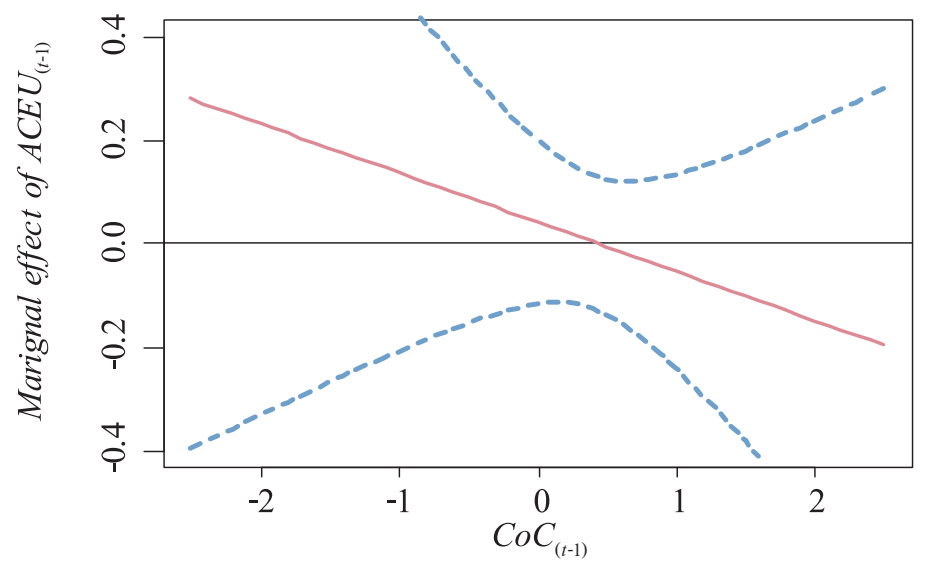

-- - 95\% Confidence interval 


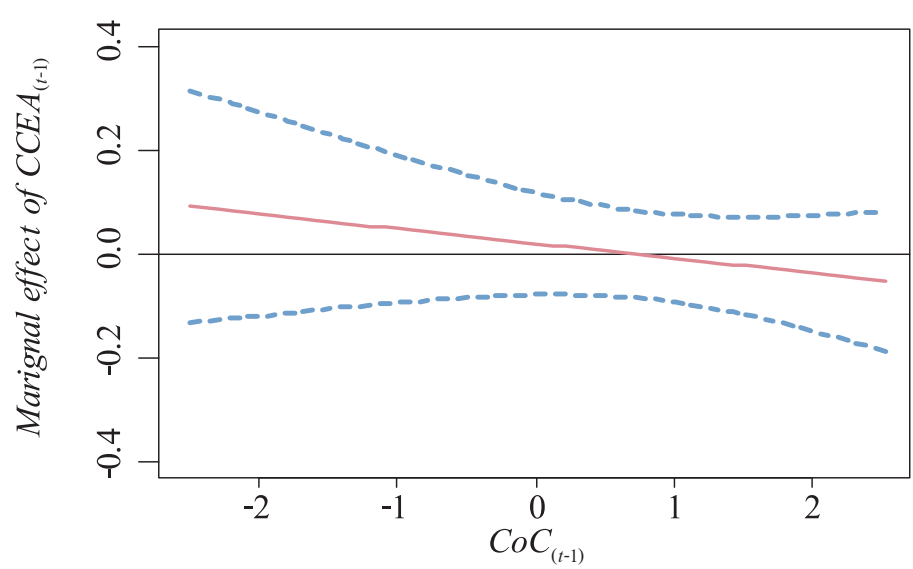

$----95 \%$ Confidence interval

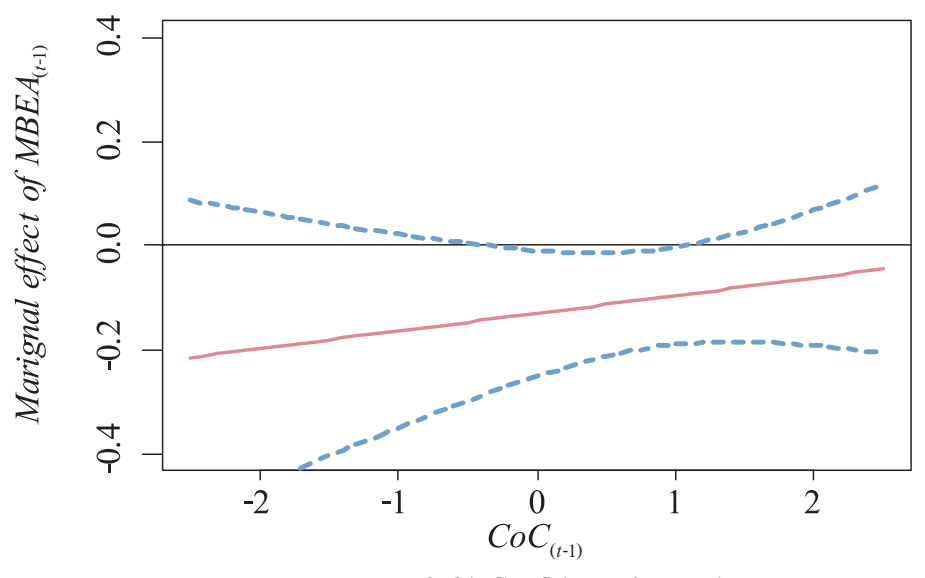

$----95 \%$ Confidence interval

(Note) CoC: Control of Corruption; MBEA: Member state in the Euro Area; CCEA: Candidate Country for the Euro Area; ACEU: Acceding Country for the EU; CCEU: Candidate Country for the EU; PCEU: Potential Candidate for the EU. 
Figure 3. Marginal effect of Status $_{t-1}$ on GE

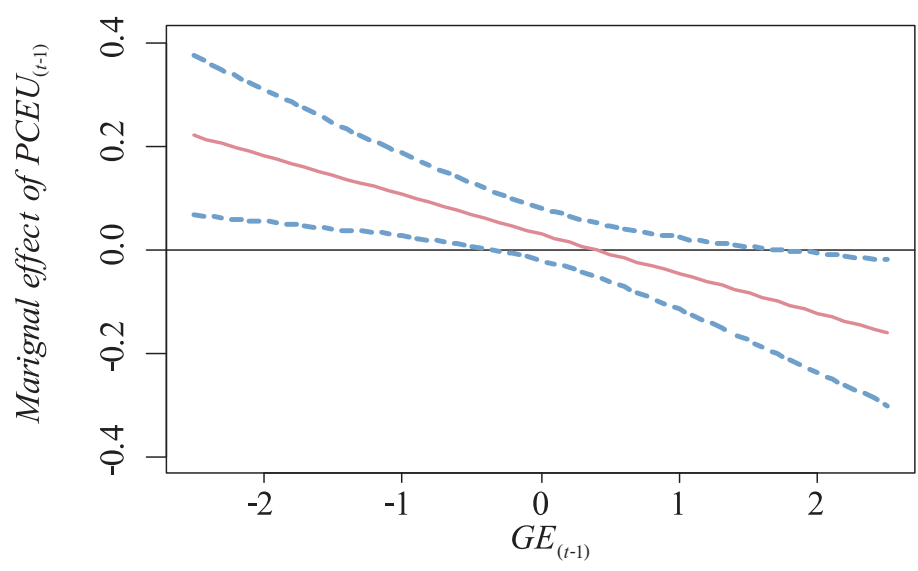

$---95 \%$ Confidence interval

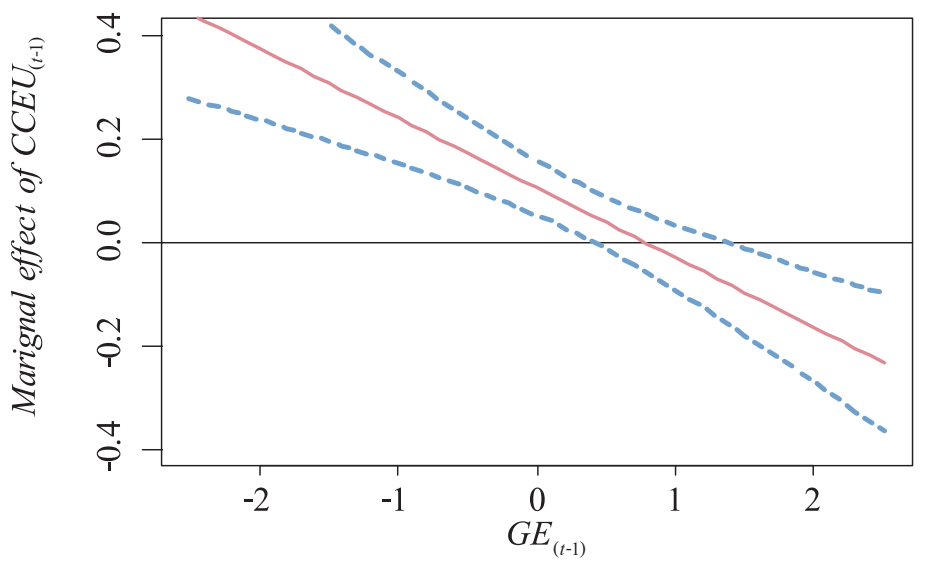

- $-95 \%$ Confidence interval

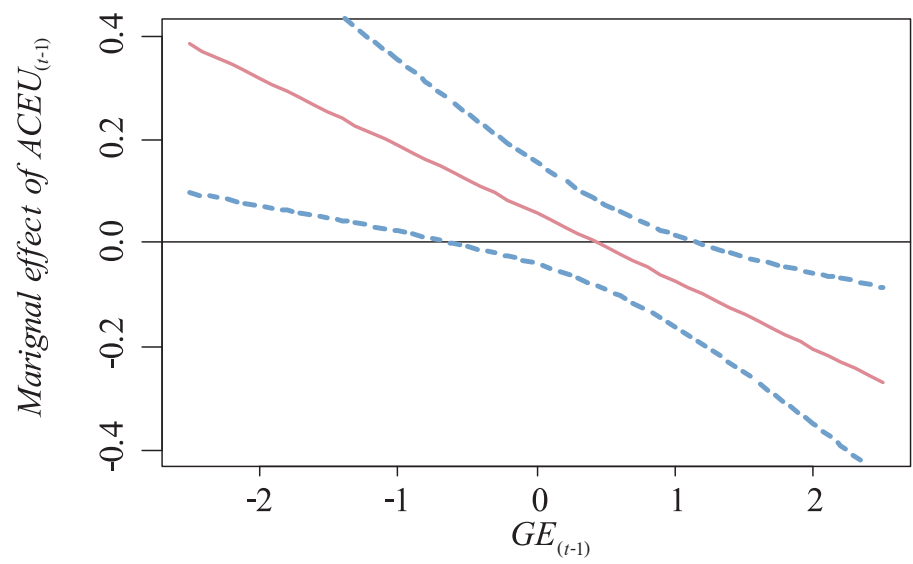

$---95 \%$ Confidence interval 

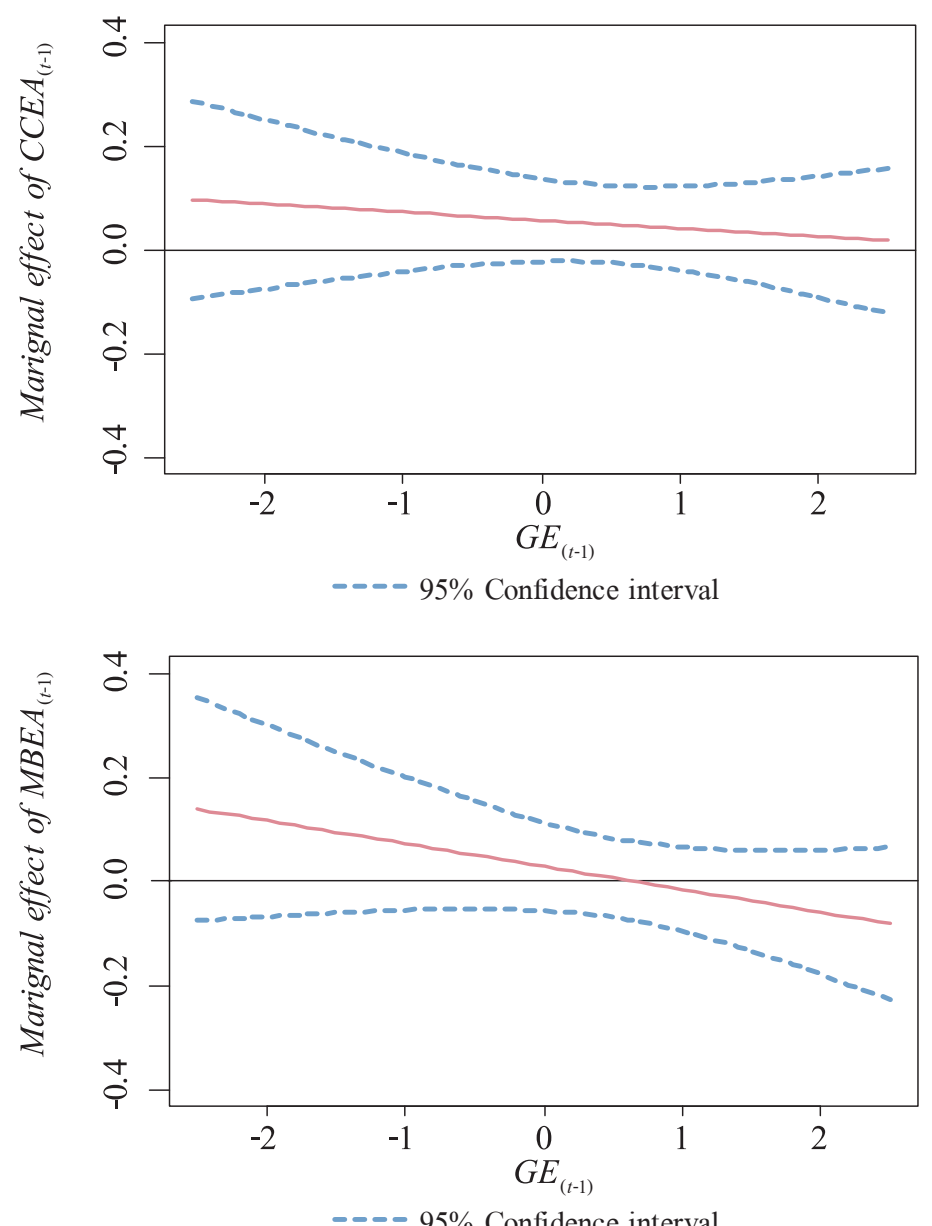

95\% Confidence interval

(Note) GE: Government Effectiveness; MBEA: Member state in the Euro Area; CCEA: Candidate Country for the Euro Area; ACEU: Acceding Country for the EU; CCEU: Candidate Country for the EU; PCEU: Potential Candidate for the EU. 
Figure 4. Marginal effect of Status $_{t-1}$ on PSNV

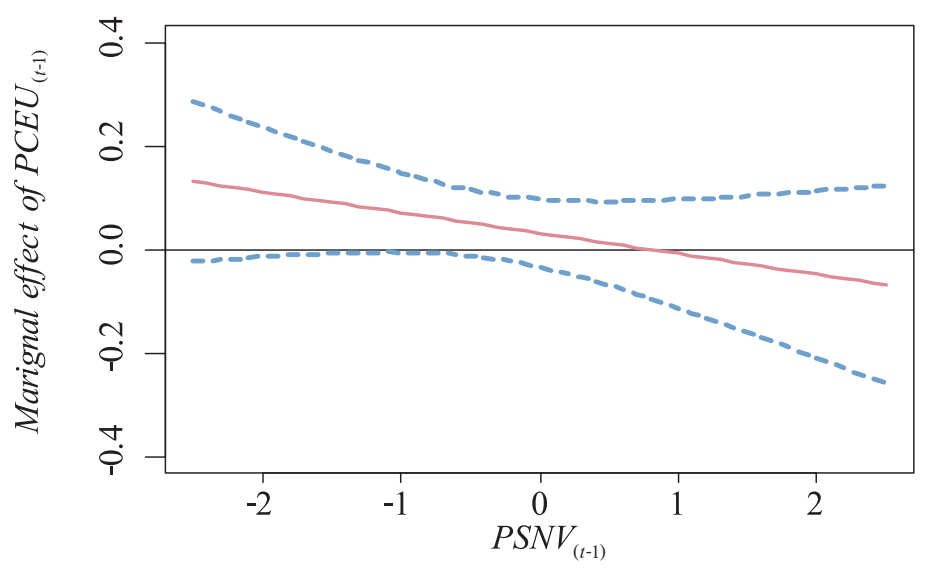

- - $-95 \%$ Confidence interval

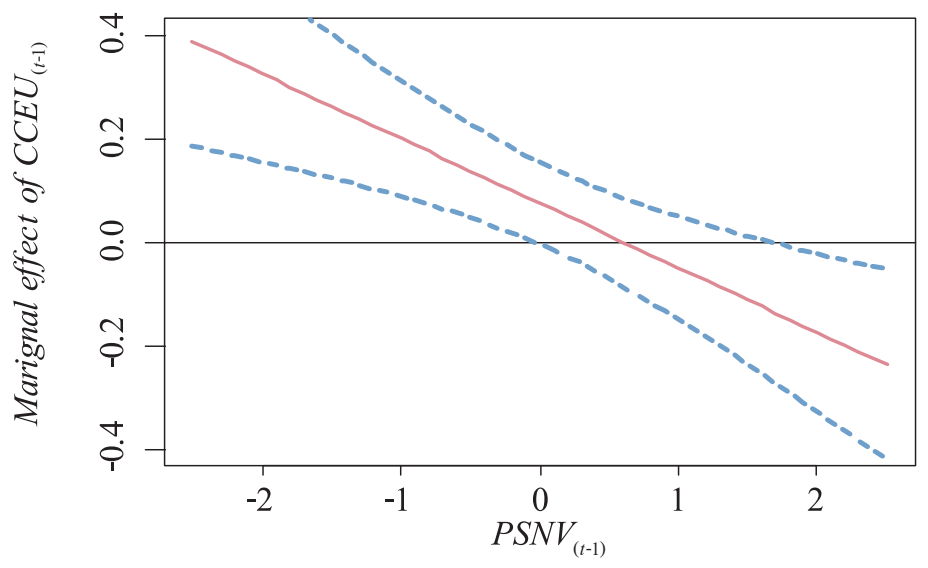

-95\% Confidence interval

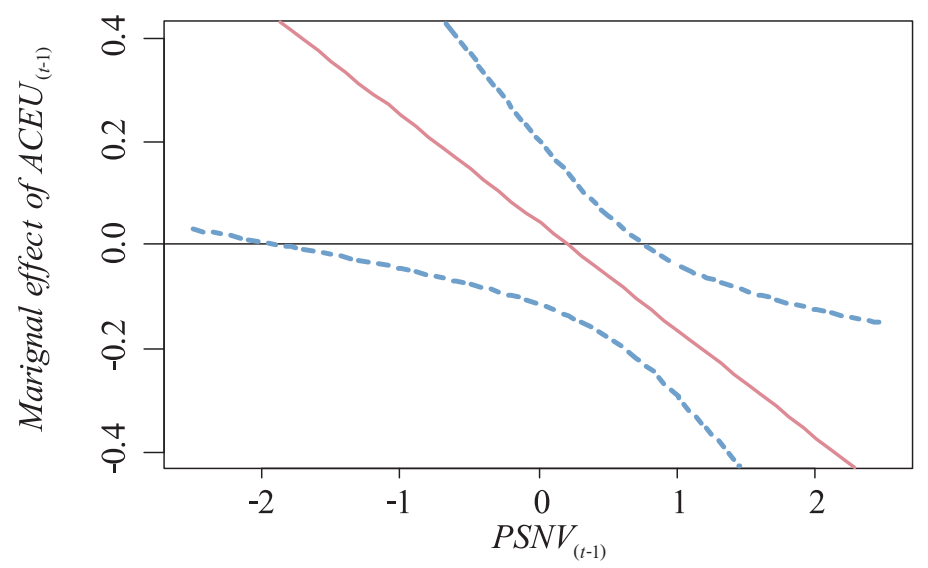

$---95 \%$ Confidence interval 

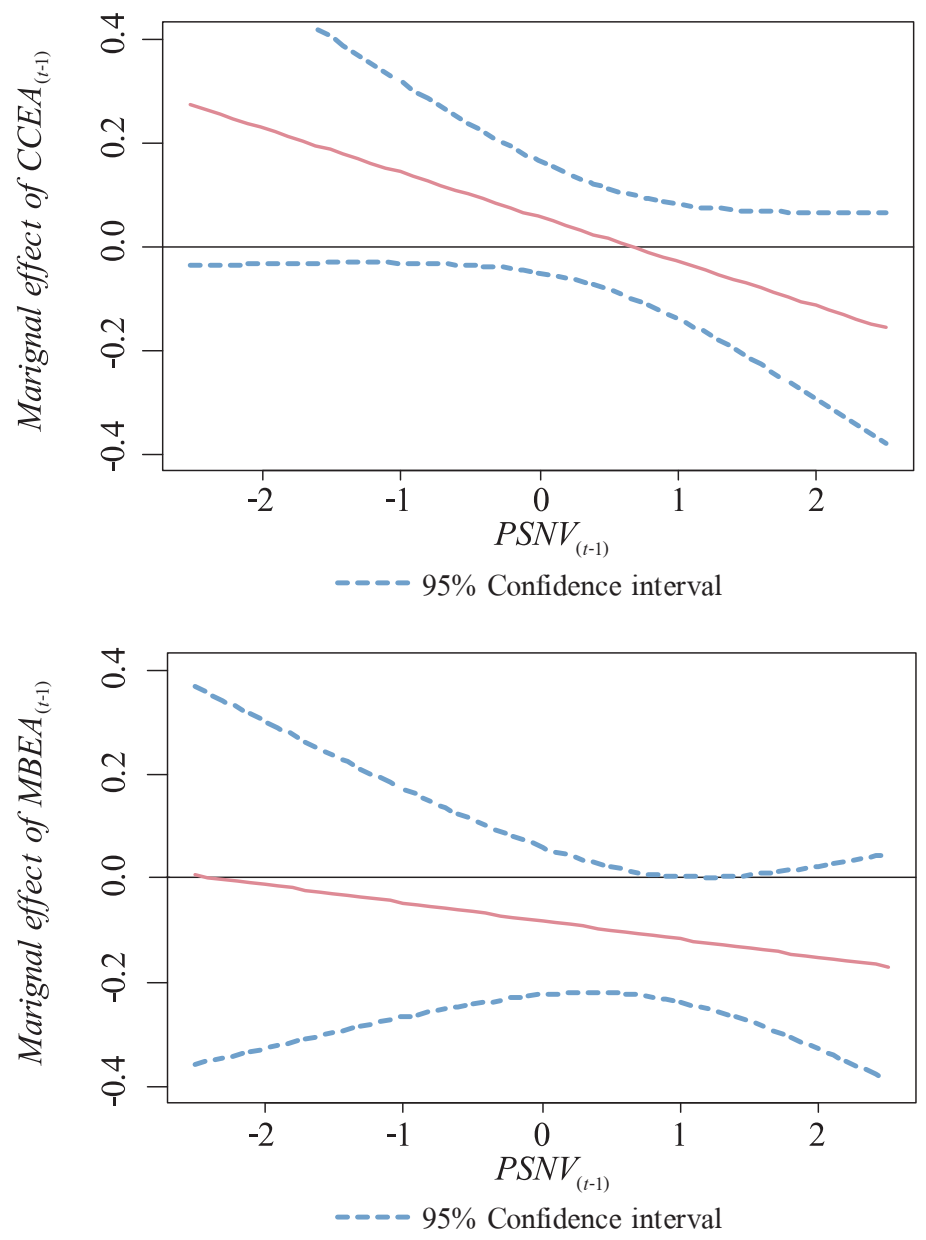

(Note) PSNV: Political Stability and Absence of Violence; MBEA: Member state in the Euro Area; CCEA: Candidate Country for the Euro Area; ACEU: Acceding Country for the EU; CCEU: Candidate Country for the EU; PCEU: Potential Candidate for the EU . 
Figure 5. Marginal effect of Status $_{t-1}$ on RoL

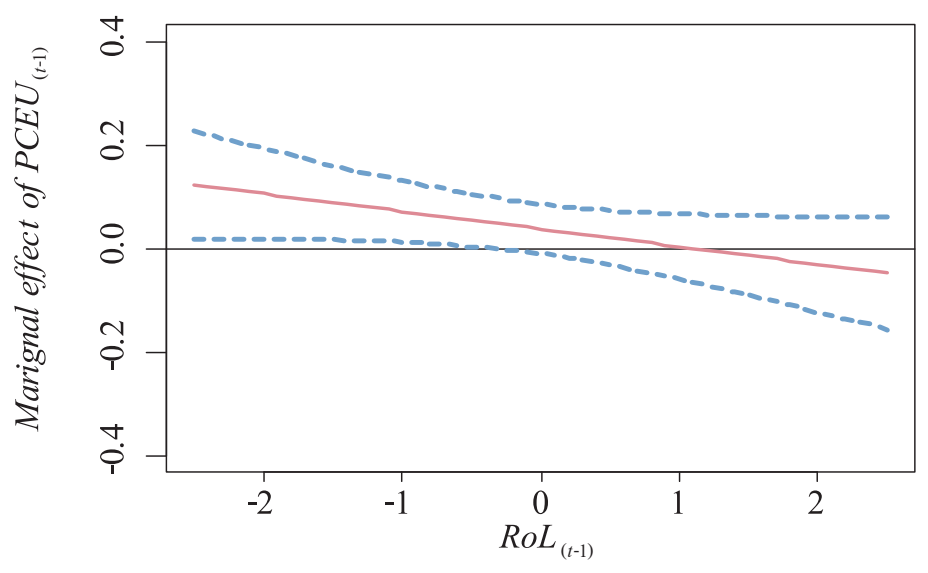

$---95 \%$ Confidence interval

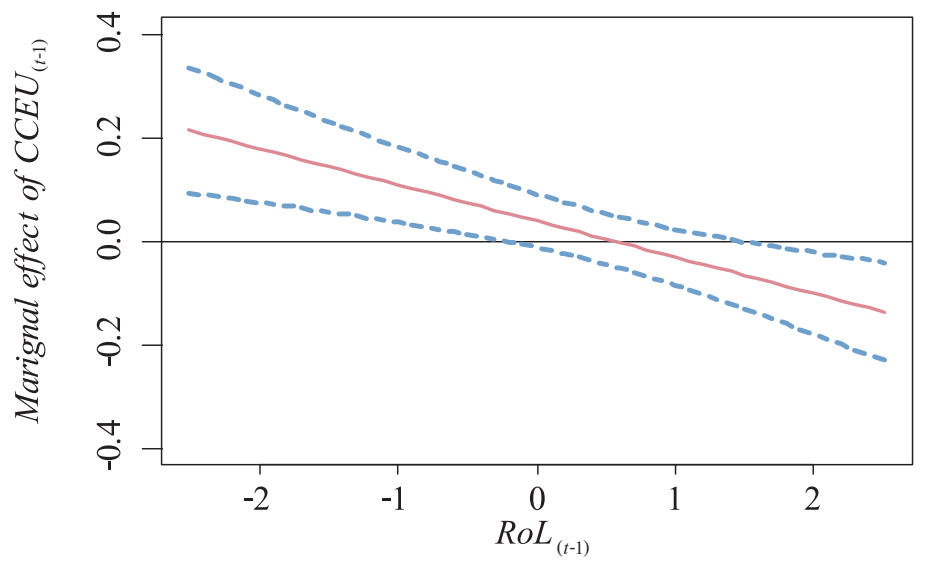

$---95 \%$ Confidence interval

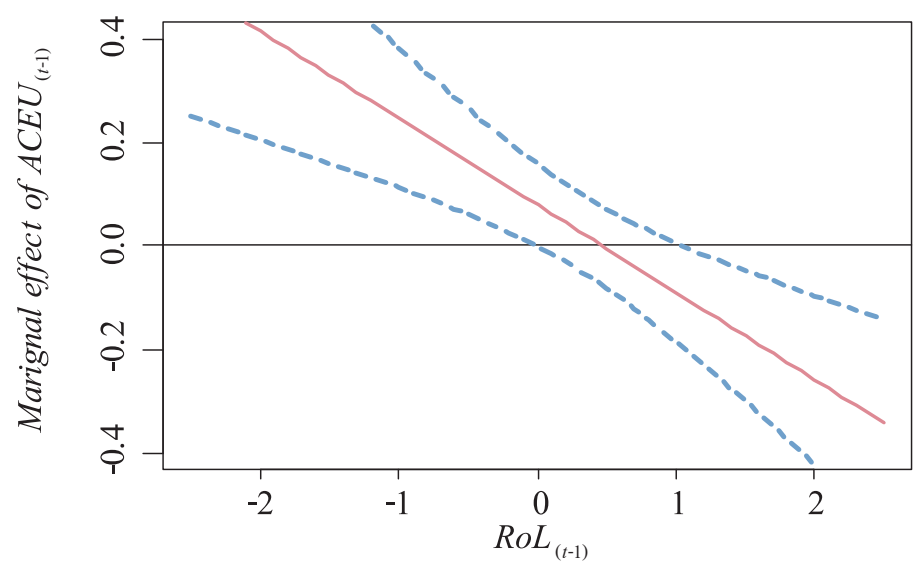

$---95 \%$ Confidence interval 

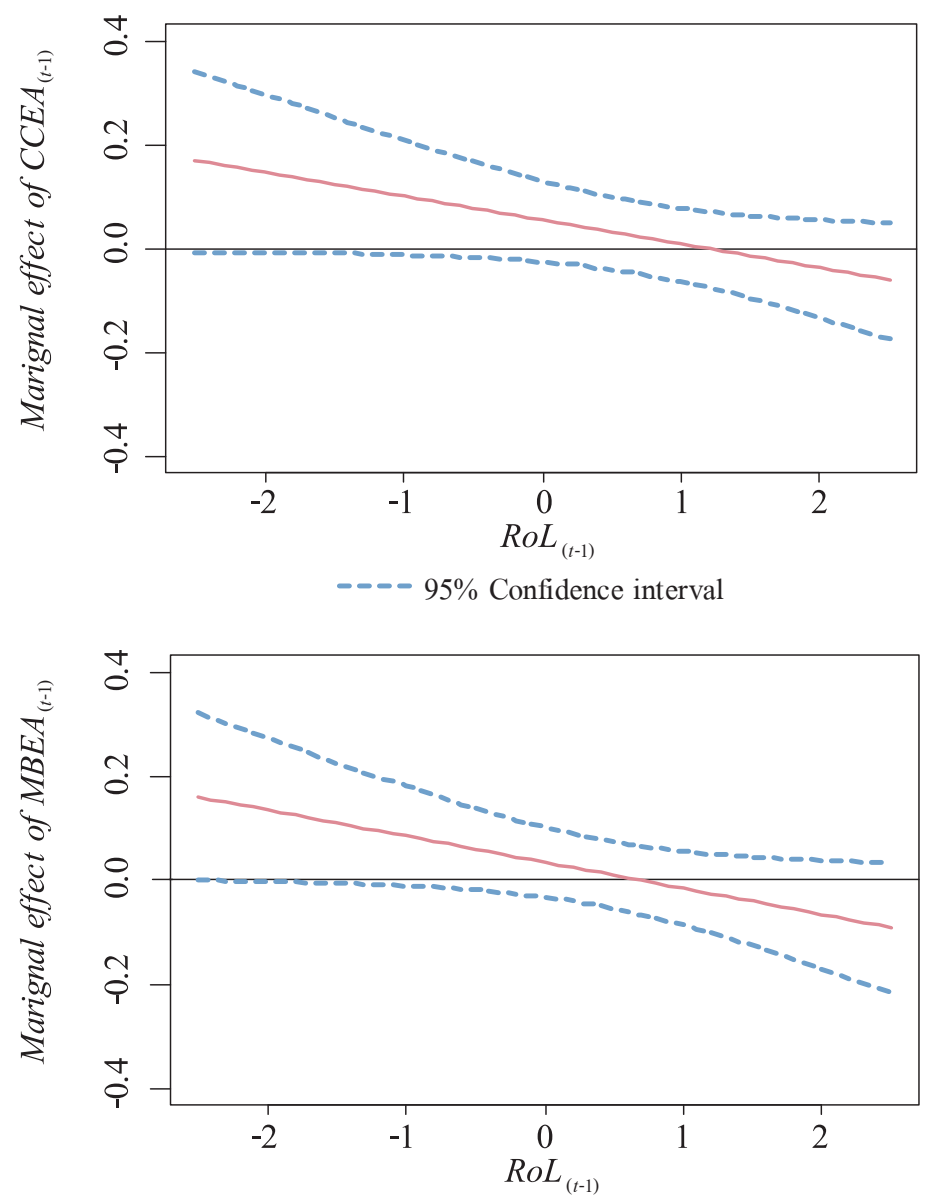

-- - $95 \%$ Confidence interval

(Note) RoL: Rule of Law; MBEA: Member state in the Euro Area; CCEA: Candidate Country for the Euro Area; ACEU: Acceding Country for the EU; CCEU: Candidate Country for the EU; PCEU: Potential Candidate for the EU. 
Figure 6. Marginal effect of Status ${ }_{t-1}$ of RQ

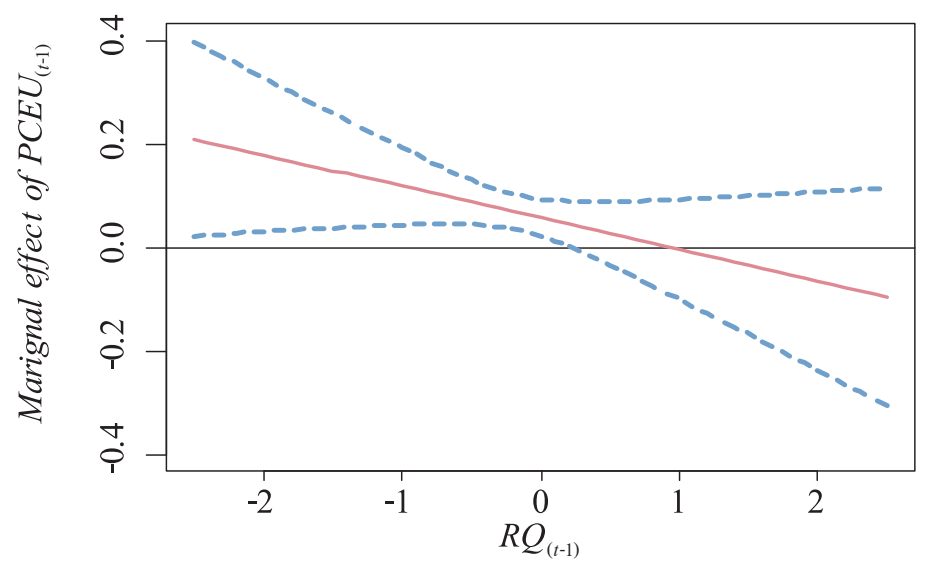

$---95 \%$ Confidence interval

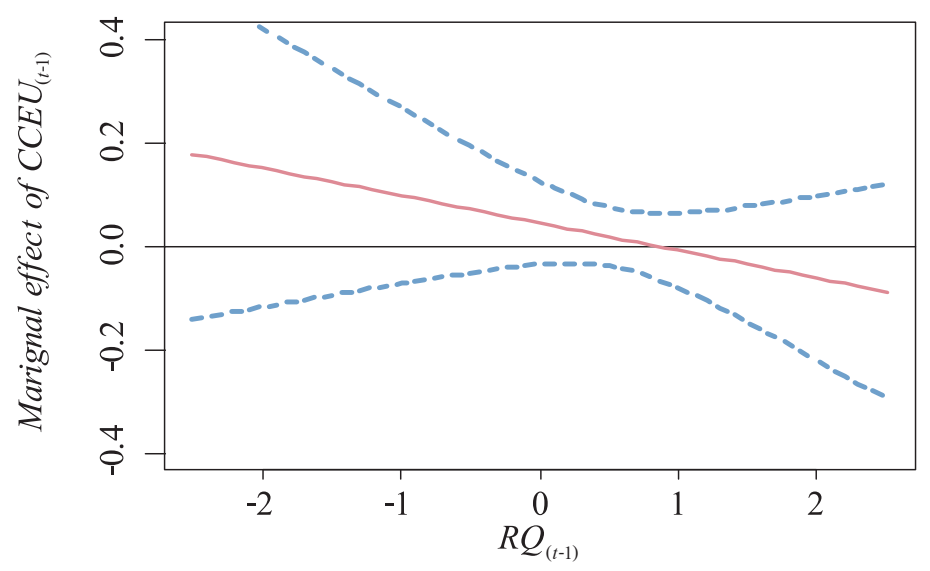

$---95 \%$ Confidence interval

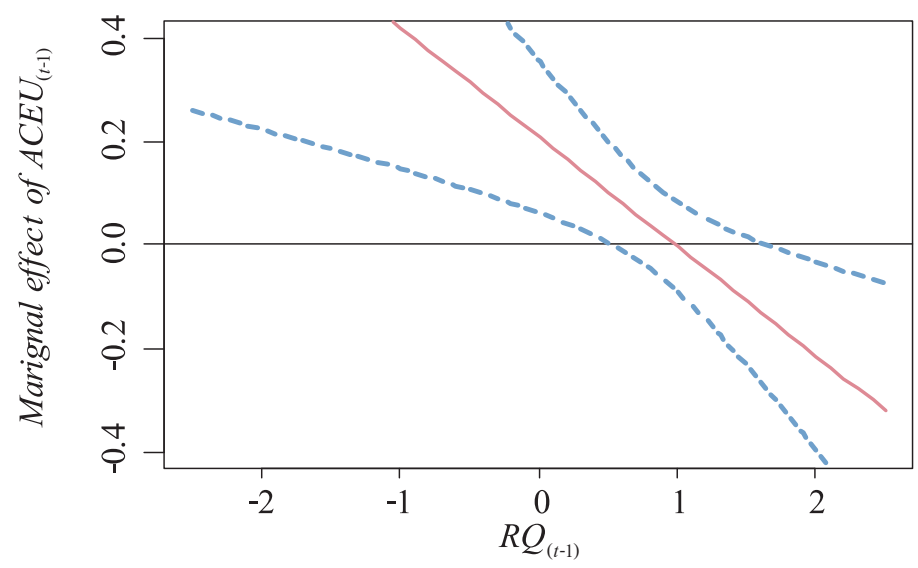

$---95 \%$ Confidence interval 


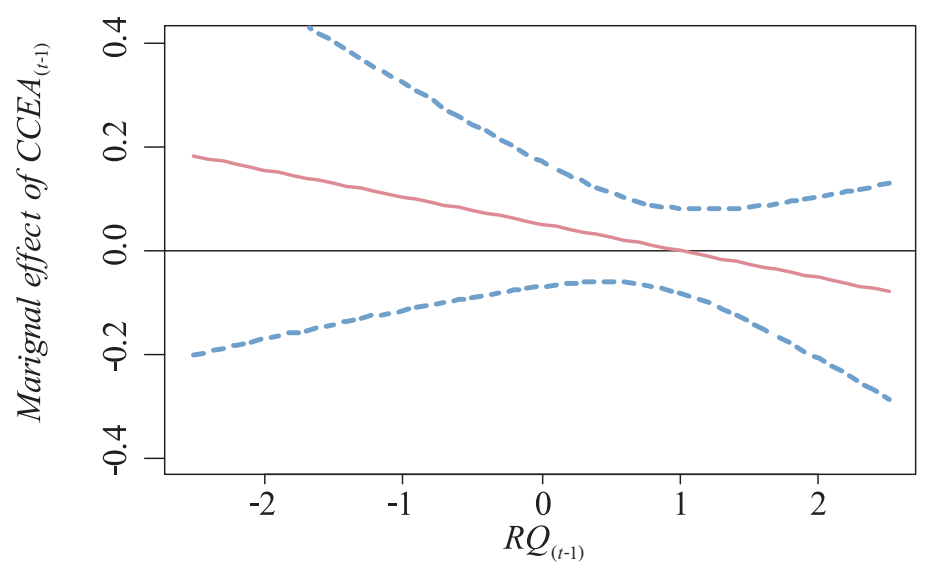

$---95 \%$ Confidence interval

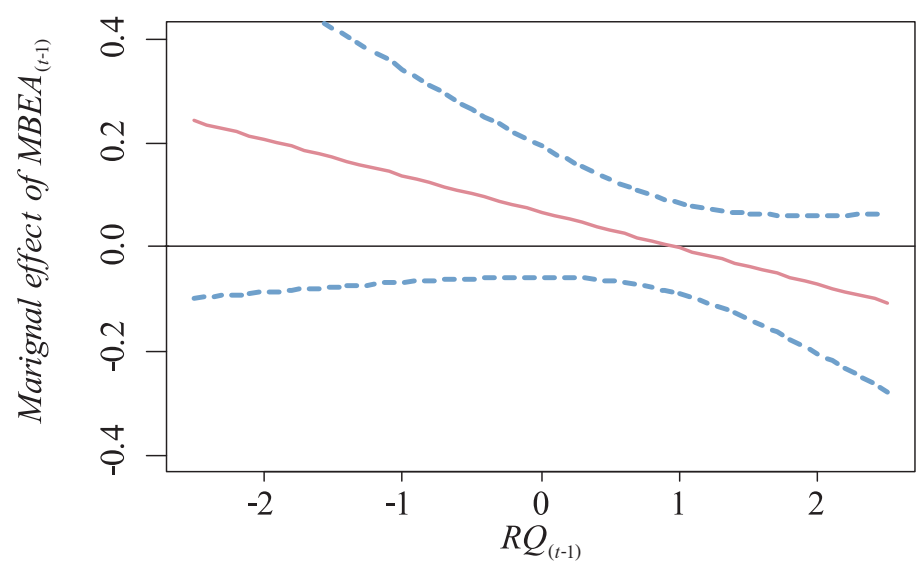

$----95 \%$ Confidence interval

(Note) RQ: Regulatory Quality; MBEA: Member state in the Euro Area; CCEA: Candidate Country for the Euro Area; ACEU: Acceding Country for the EU; CCEU: Candidate Country for the EU; PCEU: Potential Candidate for the EU. 
Figure 7. WGIs grouped by countries' status
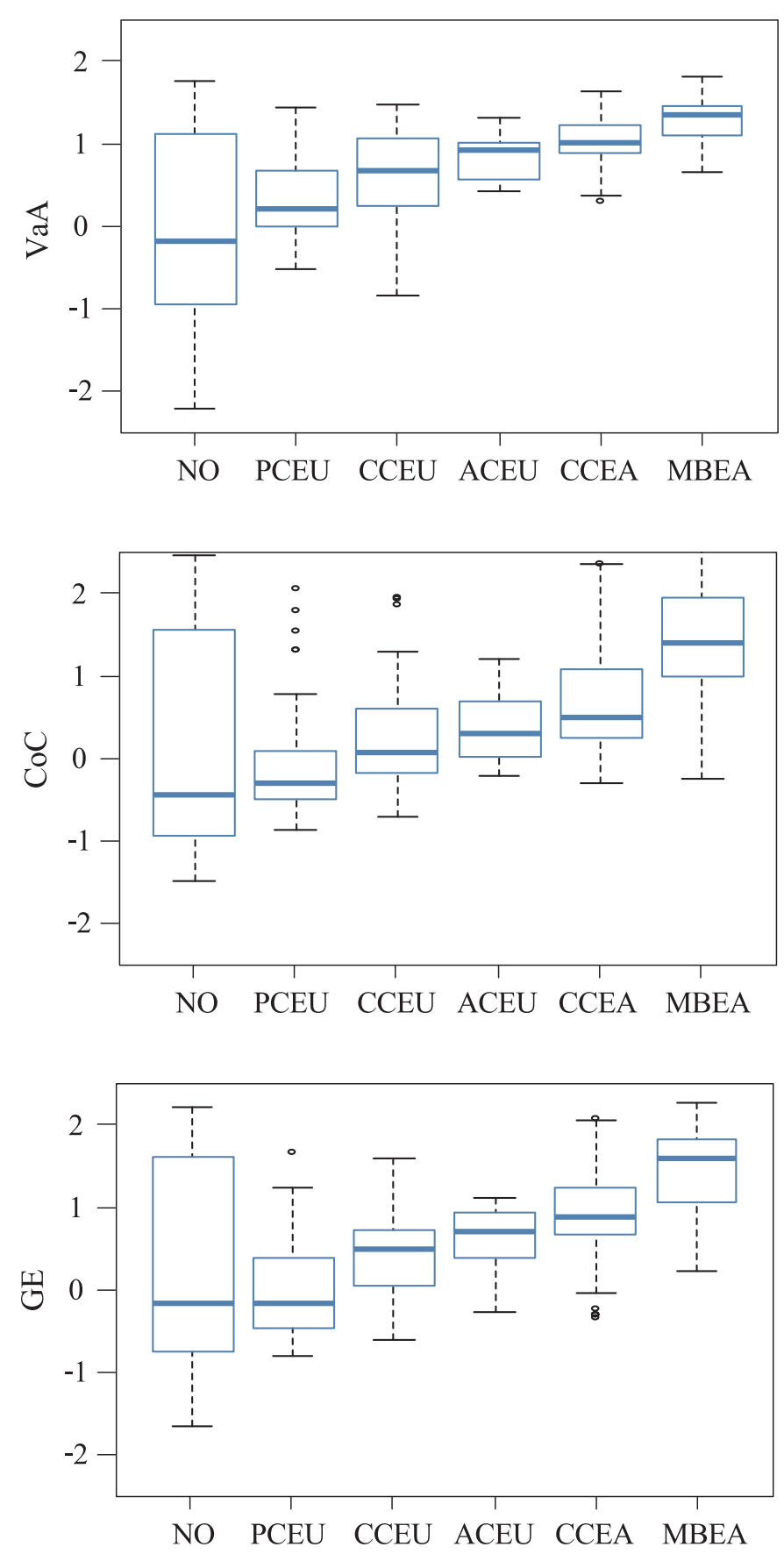

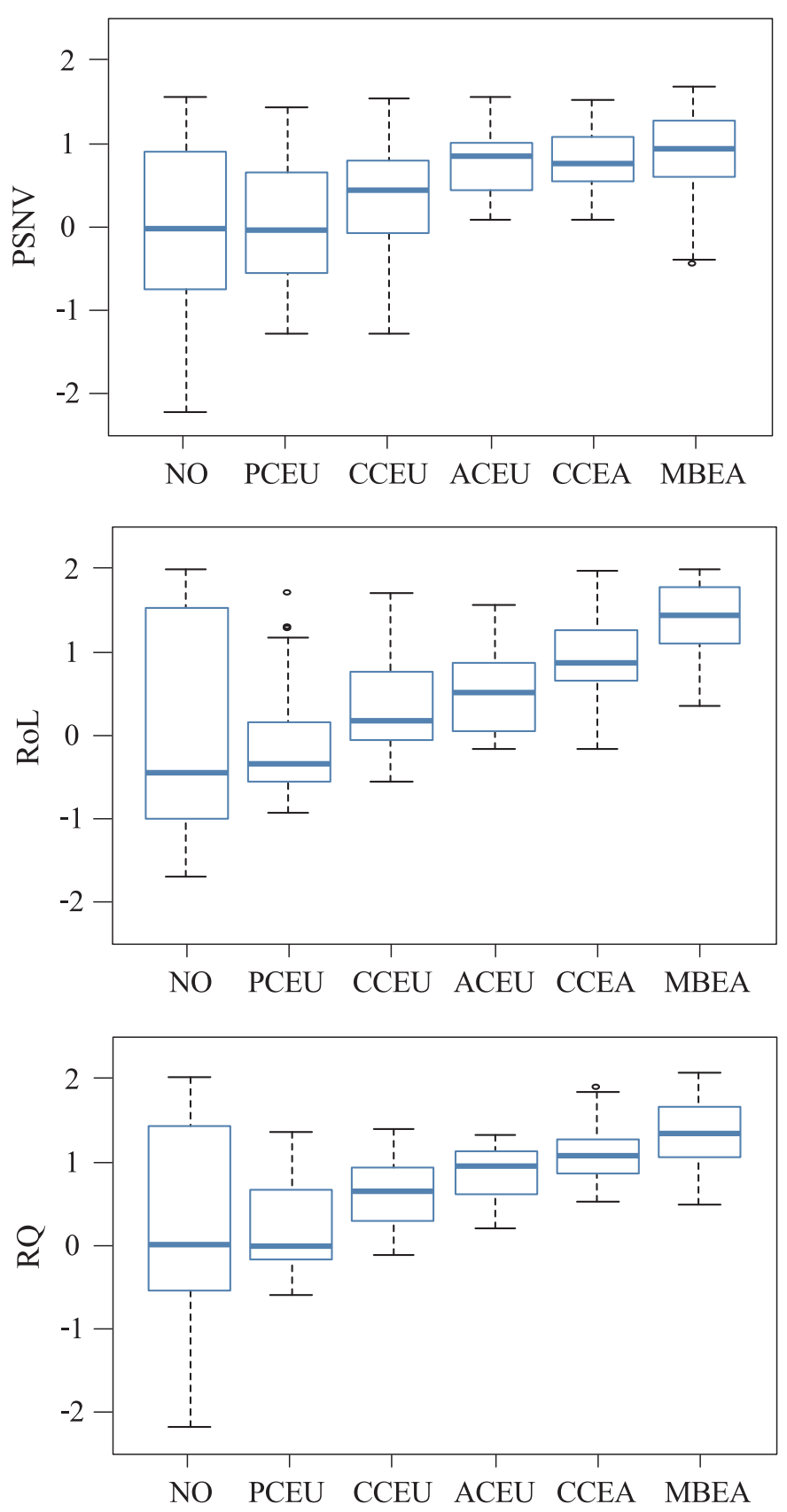

(Note) (i) The boxplots show the quartiles of the Worldwide Governance Indicators of our sample for each status of a country within the European integration process (e.g., the upper left boxplot displays the quartiles for the indicator "voice and accountability" in countries that are not involved in the European integration process). 
(ii) VaA: Voice and Accountability; CoC: Control of Corruption; GE: Goverment Effectiveness; PSNV: Political Stability and Absence of Violence; RoL: Rule of Law; RQ: Regulatory Quality.

(iii) MBEA: Member State in the Euro Area; CCEA:Candidate Country for the Euro Area; ACEU: Acceding Country for the EU; CCEU: Candidate Country for the EU; PCEU: Potential Candidate for the EU; NO: No status.

\section{B. Robustness checks}

To verify that our results are robust with respect to model and data specifications, we re-estimate Equation (1) in two different ways: first, by using biannual data and second, by second splitting the set of status dummy variables in two - one part for the issue of EU accession and the other for that of the introduction of the euro. ${ }^{26}$ Additionally, we estimate Equation (1) with biannual data using the Blundell-Bond system GMM. Our previous conclusions are largely confirmed.

The use of biannual data on the entire sample is because of the lack of WGIs for the years 1997, 1999, and 2001 (see in Section III.A). Given the small number of observations, we have to merge the statuses ACEU and CCEU. The estimates and tests are presented in the Appendix 3. The results are quite similar to those of our main specification. The coefficients of the lagged dependent variables are now more strongly downward biased, as one would expect, because of the Nickell bias. The prospect of joining the EU has direct positive effects on institutional development, which is significant for most indicators and particularly for candidate countries. Even EU member states preparing for the euro's introduction experience a positive direct effect on government effectiveness and rule of law (significant at the 10\% level). Again, being a member of the euro area is associated with significant impairment in control of corruption. With respect to the indirect effect of status, reduced persistence in candidate countries can be confirmed. This effect is highly significant for all indicators except regulatory quality. However, the bias of the coefficients on the endogenous and potentially weak exogenous variables is higher in a biannual setting as the number of periods diminishes to $T=9$. It is possible to determine the direction of the bias for the coefficient of the lagged dependent variable but not for the other regressors. Therefore,

\footnotetext{
${ }^{26}$ Additionally, we re-estimate this specification using trade with the EU and euro area instead of the overall trade as a percentage of the GDP as we believe the directions of trade to be relevant to our setting. First, the former Soviet countries displayed very tight and wide trade connections among each other just after the collapse of the Soviet Union. However, this hardly led to the import of good institutions. Second, the variables trade with the EU and trade with the euro area are probably more strongly correlated with the status of a country in the $\mathrm{EU}$ and the euro area than overall trade. However, the results basically do not change, and they are available from the authors on request.
} 
we prefer to use annual data.

The second way to confirm robustness is to split the set of status dummy variables in two, one part for the issue of EU accession and the other for the issue of introducing the euro. We estimate the effects of prospective EU membership on the WGIs and the effect of the euro's introduction and preparation to do so in two separate regressions. The statuses CCEA and MBEA are merged into the status MBEU in the regression that deals with EU accession. In addition to the countries of the baseline sample, we now include Denmark, Sweden, and UK; the reasons for excluding them are no longer applicable. The estimates and tests with the EU accession-related dummies (Appendix 4) confirm the high persistence of the WGIs, which is reduced by the prospect of entering the EU. In addition, the direct effects of prospective EU membership on the WGIs are the same overall as in the baseline regression. Being a candidate country accelerates government effectiveness and induces political stability and absence of violence. Being an acceding country contributes positively to voice and accountability, rule of law, and regulatory quality. Potential candidate countries experience an improvement only in regulatory quality. Moreover, there is a positive and significant direct effect of being a EU member state on government effectiveness. Concerning the introduction of the euro, there are only three statuses: NO, CCEA, and MBEA. The high persistence of the WGIs is confirmed as well as the negative direct effect of euro-area membership on control of corruption (Appendix 5). Moreover, euro-area membership increases the persistence of control of corruption, which is also the case for preparation to introduce the euro on the rule of law.

The use of biannual data reduces the number of observation periods, which allows the application of the system GMM estimator proposed by Blundell and Bond (1998). To avoid the problem of instrument proliferation, we limit the instrument count by (1) restricting the lags to be used for instruments instead of using all available lags and (2) collapsing the instrument matrix. The estimates, significance tests, and specification tests are reported in Appendix 6. The GMM results are very weak for political stability and absence of violence, and regulatory quality, for which the coefficients of the status variables and the interaction terms are insignificant. Prospective EU membership contributes directly and positively to voice and accountability and reduces persistence of voice and accountability, control of corruption, and government effectiveness. Regarding membership in the euro area, the negative impact on control of corruption is again confirmed. The GMM results also show a significant negative impact of being a euroarea member on rule of law. In contrast, we see a positive influence of being a euro-area 
member on the development of voice and accountability. By and large, the GMM results confirm our previous conclusions.

\section{Control of corruption in the Euro Area}

The finding of a negative effect in terms of control of corruption in euro-area countries, particularly among those with a low institutional development level, is somewhat surprising and deserves some explanation. Unfortunately, we cannot provide a definitive answer on the reasons here, ${ }^{27}$ but we borrow from the literature on monetary policy design and attempt to explain it through economic reasoning.

In a model of monetary policy design, wherein the government's objective function includes the provision of public goods in addition to stabilizing output and inflation, Huang and Wei (2006) integrate the level of institutional quality. They introduce the level of institutional quality by specifying fiscal capacity, which is the ability of the government to collect tax revenue. The weaker the control of corruption, the higher are the leakage between the tax rate and the portion that accrues to the government as tax revenue. Hefeker (2010) and Dimakou (2013) contributed some extensions to this model. Although the literature focuses on developing or transition countries, the model implications can be related to euro-area members with relatively high corruption. In particular, these countries are Greece, Italy, and several new EU member states that recently introduced the euro.

Hefeker (2010) shows that a unilateral peg to a low-inflation country leads to a loss of seigniorage, which tightens the government's budget constraint. Two options remain available to the government to raise revenue: (1) increase the tax rate or (2) fight corruption. The government will rely on both instruments. In our opinion, Hefeker (2010) elaborates one of the two crucial effects that apply to the euro area. On the one hand, the budget constraint of high-corruption countries has been hardened because inflation and seigniorage has gone down. This should have forced the government to fight corruption. On the other hand - and this is specific to the euro area before the European sovereign debt crisis - the budget constraint became looser because risk premia on interest rates went down and large amounts of foreign capital flew to countries with relatively high levels of corruption. This probably had the opposite effect on corruption (see also the

\footnotetext{
${ }^{27}$ This will require a formal model to be tested empirically in a follow-up paper.
} 
arguments of Fernández-Villaverde et al. 2013 in Section II.A). ${ }^{28}$ The negative interest rate effect on the control of corruption has probably dominated in high-corruption euro-area members, as indicated by our empirical findings. A further loosening of governments' budget constraints might be caused by the redistribution of funds from the EU budget. Net beneficiaries of the EU budget tend to be member states with low incomes and high corruption. Moreover, accountability for efficient spending of these funds might be lower compared with taxes, which facilitates corruption. During the European sovereign debt crisis, rising poverty and unemployment could have also contributed to rising incentives for corruption, as observed in Greece since 2011.

\section{Conclusion}

In this paper, we investigated the direction of institutional development induced by European integration. We can confirm a positive effect of EU enlargement on institutional development, albeit not along every dimension of governance when applying system GMM. The positive effect of EU enlargement operates mainly by reducing the persistence of institutional development. Countries with relatively low levels of institutional development benefit most from prospective EU membership. Hence, we can confirm the results of the empirical literature on the transition countries of Central and Eastern Europe.

The novel finding of this paper is that once countries have become EU member states or even introduced the euro, their institutional development loses momentum. The concerns that new EU member states could quickly reverse their reforms, however, are not supported empirically. Nonetheless, we have robust evidence indicating that members of the euro area underperform in one particular area of institutional development: control of corruption.

To prove that our findings are robust with respect to the choice of the indicator for institutional development, the analysis should be replicated with alternative indicators. There are already some empirical studies examining the impact of prospective EU

\footnotetext{
${ }^{28}$ Hefeker (2010) states explicitly that a hard peg, like dollarization, might lower the interest rate because reneging on the peg is less likely. However, he admits neglecting this effect in his model. This is reasonable for dollarization in or a monetary union between developing or transition countries, but does evidently not fit to the developments in the euro area.
} 
membership upon institutional development that apply indicators other than the WGIs. The most widely used alternative indicators in this context are the European Bank for Restruction and Development (EBRD) transition indicators. Hence, we see a great need of replication concerning euro-area membership and its preparation. We leave this task for future research. Moreover, we are aware of the weaknesses of the currently available estimators for analyzing macroeconomic dynamic panel data models. We hope for substantial progress in this area of econometrics.

Received 24 May 2016, Revised 22 June 2016, Accepted 19 July 2016

\section{References}

Acemoglu, Daron, and Simon Johnson. "Unbundling Institutions." Journal of Political Economy 113 (5) (2005): 949-95.

Acemoglu, Daron, Simon Johnson, and James A. Robinson. "Chapter 6 Institutions as a Fundamental Cause of Long-Run Growth." In Handbook of Economic Growth. Vol. 1, edited by Philippe Aghion and Steven N. Durlauf, 385-472: Elsevier (2005).

Acemoglu, Daron, and James A. Robinson. Why nations fail: The origins of power, prosperity, and poverty. London: Profile Books (2012).

Alesina, Alberto, Silvia Ardagna, and Vincenzo Galasso. "The Euro and Structural Reforms." Review of Economics and Institutions 2 (1) (2010): 1-37.

Aron, Janine. "Growth and Institutions: A Review of the Evidence." The World Bank Research Observer 15 (1) (2000): 99-135.

Ballabriga, Fernando, and Carlos Martinez-Mongay. "A Further Inquire About the Sustainability of Fiscal Policy in the EU." In Fiscal Indicators: Proceedings from the Directorate-General for Economic and Financial Affairs Workshop Brussels, 22 September (2006), edited by Martin Larch and João Nogueira Martins, 17-55. European Economy - Economic Papers 297. Brussels: Europ. Comm. Directorate-General for Economic and Financial Affairs. 
Baltagi, Badi H. Econometric analysis of panel data. 4th ed. Chichester, West Sussex: Wiley (2008).

Bayar, Ali, and Bram Smeets. "Economic, political and institutional determinants of budget deficits in the European Union.” CESifo Working Papers 2611 (2009).

Bean, Charles R. "The interaction of aggregate-demand policies and labour market reform." Swedish Economic Policy Review 5 (2) (1998): 353-82.

Beck, Thorsten, and Luc Laeven. "Institution building and growth in transition economies." Journal of Economic Growth 11 (2) (2006): 157-86.

Belke, Ansgar, Bernhard Herz, and Lukas Vogel. "Reforms, Exchange Rates and Monetary Commitment: A Panel Analysis for OECD Countries." Open Economies Review 18 (3) (2007): 369-88.

Belke, Ansgar, and Lukas Vogel. "Monetary commitment and structural reforms: a dynamic panel analysis for transition economies." International Economics and Economic Policy 12 (3) (2015): 375-92.

Berglöf, Erik, Mike Burkart, Guido Friebel, and Elena Paltseva. "Widening and Deepening: Reforming the European Union." The American Economic Review 98 (2) (2008): 133-37.

_C "Club-in-the-club: Reform under unanimity." Journal of Comparative Economics 40 (3) (2012): 492-507.

Berglöf, Erik, and Gérard Roland. "The EU as an "outside anchor" for transition reforms." SITE working paper 132 (1997).

Blundell, Richard W., and Stephen R. Bond. "Initial conditions and moment restrictions in dynamic panel data models." Journal of Econometrics 87 (1) (1998): 115-43.

Brambor, Thomas, William R. Clark, and Matt Golder. "Understanding Interaction Models: Improving Empirical Analyses.” Political Analysis 14 (1) (2006): 63-82.

Breitung, Jörg. "Estimating Dynamic Panel Data Models: A Comparison of Different Approaches." Discussion papers 1. Unpublished manuscript. http://www.ect.uni-bonn. de/publikationen/panel.pdf.

."The Analysis of Macroeconomic Panel Data." In The Oxford Handbook of Panel Data, edited by Badi H. Baltagi, 453-92: Oxford University Press (2015). 
Brücker, Herbert, Philipp J. H. Schröder, and Christian Weise. "Can EU Conditionality Remedy Soft Budget Constraints in Transition Countries?" Journal of Comparative Economics 33 (2) (2005): 371-86.

Cameron, Adrian C., and Pravin K. Trivedi. Microeconometrics: Methods and Applications. reprint. Cambridge: Cambridge Univ. Press (2007).

Croissant, Yves, and Giovanni Millo. "Panel Data Econometrics in R: The plm Package.” Journal of Statistical Software 27 (2) (2008): 1-43.

Crombrugghe, Alain d., Zanny Minton-Beddoes, and Jeffrey Sachs. "EU Membership for Central Europe: Commitments, Speed, and Conditionality." Working Papers 523. Harvard Institute for International Development. Cambridge, Mass (1996).

Di Tommaso, Maria L., Martin Raiser, and Melvyn Weeks. "Home Grown or Imported? Initial Conditions, External Anchors and the Determinants of Institutional Reform in the Transition Economies.” The Economic Journal 117 (520) (2007): 858-81.

Dimakou, Ourania. "Monetary and fiscal institutional designs." Journal of Comparative Economics 41 (4) (2013): 1141-66.

Dixit, Avinash K. "Economic Governance." In The New Palgrave Dictionary of Economics, edited by Steven N. Durlauf and Lawrence E. Blume. 2nd ed. The New Palgrave Dictionary of Economics Online. Basingstoke: Palgrave Macmillan. http:// www.dictionaryofeconomics.com/extract?id=pde2008_E000260. Accessed January 14, 2013.

Dollar, David, and Aart Kraay. "Institutions, trade, and growth." Journal of Monetary Economics 50 (1) (2003): 133-62.

Drazen, Allan. Political economy in macroeconomics. Princeton, NJ: Princeton Univ. Press (2000).

Duval, Romain, and Jørgen Elmeskov. "The Effects of EMU on Structural Reforms in Labour and Product Markets." OECD Economics Department Working Papers 438 (2005).

Eijffinger, Sylvester C. W., and Patrick Stadhouders. "Monetary policy and the rule of law." CEPR Discussion Paper Series 3698 (2003).

European Central Bank. "The European Central Bank, The Eurosystem, The European 
System of Central Banks." Available online at http:/www.ecb.eu/pub/pdf/other/escb_ web_2011en.pdf?ce1ae83f168a8c88450c3e7aac3283f3. Accessed April 12, 2012.

int/pub/pdf/conrep/cr201205en.pdf, Accessed August 22, 2012.

European Commission. "Enlargement of the European Union: An Historic Opportunity." Available online at http://bookshop.europa.eu/en/enlargement-of-the-european-unionpbNIXX03001/?CatalogCategoryID=3vgKABstSD8AAAEj4IUY4e5K, Accessed December 04, 2012.

_. "Enlargement." Available online at http://ec.europa.eu/enlargement/index en.htm. Accessed December 04, 2012.

European Council. "European Council in Copenhagen 21-22 JUNE 1993: Conclusions of the Presidency." News release. http://europa.eu/rapid/press-release_DOC-93-3_ en.htm. Accessed April 03, 2013.

. "Conclusions from 2002 to 1993." http://www.european-council.europa.eu/ council-meetings/conclusions/archives-2002-1993. Accessed December 04 (2012).

—. "EUROPA - European Union website, the official EU website: How the EU works, Countries.” http://europa.eu/about-eu/countries/index_en.htm. Accessed December 04, 2012.

Fernández-Villaverde, Jesús, Luis Garicano, and Tano Santos. "Political Credit Cycles: The Case of the Eurozone." Journal of Economic Perspectives 27 (3) (2013): 145-66.

Fox, John, and Sanford Weisberg. An R Companion to Applied Regression. 2nd ed. Thousand Oaks CA: Sage (2011).

Galli, Emma, and Fabio Padovano. "Sustainability and determinants of Italian public deficits before and after Maastricht." In Sustainability of public debt, edited by Reinhard Neck and Jan-Egbert Sturm, 51-83. CESifo seminar series. Cambridge, Mass. MIT Press (2008).

Glaeser, Edward L., Rafael La Porta, Florencio Lopez-de-Silanes, and Andrei Shleifer. “Do Institutions Cause Growth?” Journal of Economic Growth 9 (3) (2004): 271-303.

Gleich, Holger. "Budget institutions and fiscal performance in Central and Eastern European Countries." Working Paper Series 215 (2003). European Central Bank. 
Frankfurt am Main.

Haan, Jakob d. "Political Institutions and Economic Growth Reconsidered: Presidential Address for the European Public Choice Society Conference, Turku, April 2006." Public Choice 131 (3-4) (2007): 281-92.

Hefeker, Carsten. "Taxation, corruption and the exchange rate regime." Journal of Macroeconomics 32 (1) (2010): 338-46.

Huang, Haizhou, and Shang-Jin Wei. "Monetary policies for developing countries: The role of institutional quality." Journal of International Economics 70 (1) (2006): 239-52.

Judson, Ruth A., and Ann L. Owen. 1999. "Estimating dynamic panel data models: a guide for macroeconomists." Economics Letters 65 (1) (1999): 9-15.

Jütting, Johannes P. "Institutions and Development: A Critical Review." OECD Development Centre Working Papers 210 (2003).

Kam, Cindy D., and Robert J. Franzese. "Modeling and interpreting interactive hypotheses in regression analysis: A Refrecher and Some Pactical Advice.” http:// investigadores.cide.edu/aparicio/data/Kam\%26Franzese_InterpretingInteractionsinRegre ssions_05.pdf. Accessed January 07, 2015.

Kaufmann, Daniel, Aart Kraay, and Massimo Mastruzzi. "The Worldwide Governance Indicators Project: Answering the Critics." Policy Research Working Paper 4149. World Bank. Washington, DC (2007).

—. "The Worldwide Governance Indicators: Methodology and Analytical Issues." Policy Research Working Paper 5430. World Bank. Washington, DC (2010).

—. "The Worldwide Governance Indicators (WGI) project." World Bank. http:// info.worldbank.org/governance/wgi/index.aspx\#home. Accessed October 22 (2013).

Kochenov, Dimitry. EU enlargement and the failure of conditionality: Pre-accession conditionality in the fields of democracy and the rule of law. European monographs 59. Austin: Kluwer Law International; Wolters Kluwer (2008).

Kohn, Meir. "Economic Development and Growth: A Survey." Cato Journal 29 (2) (2009): 237-46.

Mattli, Walter, and Thomas Plümper. "The Internal Value of External Options: How the EU Shapes the Scope of Regulatory Reforms in Transition Countries." European Union 
Politics 5 (3) (2004): 307-30.

Mink, Mark, and Jakob d. Haan. "Has the stability and growth pact impeded political budget cycles in the European Union?” CESifo working paper series 1532 (2005).

Nickell, Stephen. "Biases in Dynamic Models with Fixed Effects." Econometrica 49 (6) (1981): 1417-26.

North, Douglass C. Structure and change in economic history. New York NY: Norton (1981).

- Institutions, institutional change and economic performance. 28th ed. Cambridge: Cambridge Univ. Press (1990).

R Core Team. 2012. R: A Language and Environment for Statistical Computing. Vienna, Austria: R Foundation for Statistical Computing. http://www.R-project.org/. Accessed May 12 (2013).

Rigobon, Roberto, and Dani Rodrik. "Rule of law, democracy, openness, and income." Economics of Transition 13 (3) (2005): 533-64.

Roland, Gérard. Transition and economics. Comparative institutional analysis 1. Cambridge, Mass: MIT Press (2000)

Roland, Gérard, and Thierry Verdier. "Law enforcement and transition." European Economic Review 47 (4) (2003): 669-85.

Roodman, David. “A Note on the Theme of Too Many Instruments.” Oxford Bulletin of Economics and Statistics 71 (1) (2009): 135-58.

Saint-Paul, Gilles, and Samuel Bentolila. "Will EMU Increase Eurosclerosis?" In The Impact of EMU on Europe and the Developing Countries: A Study Prepared for the World Institute for Development Economics Research of the United Nations University (UNU/WIDER), edited by Charles Wyplosz, (2011): 128-68. UNU/WIDER studies in development economics. Oxford: Oxford Univ. Press.

Schweickert, Rainer, Inna Melnykovska, Ansgar Belke, and Ingo Bordon. "Prospective NATO or EU membership and institutional change in transition countries." The Economics of Transition 19 (4) (2011): 667-92.

Shirley, Mary M. "Institutions and development." In Handbook of new institutional economics, edited by Claude Ménard and Mary M. Shirley, (2005): 611-38. Dordrecht: 
Springer.

Staehr, Karsten. "Democratic and Market-Economic Reforms in the Postcommunist Countries: The Impact of Enlargement of the European Union." Eastern European Economics 49 (5) (2011): 5-28.

Voigt, Stefan. "How (Not) to measure institutions." Journal of Institutional Economics 9 (1) (2013): 1-26.

Weber, Steven. "European Union conditionality." In Politics and institutions in an integrated Europe, edited by Barry J. Eichengreen, (1995):193-220. Berlin: Springer.

Windmeijer, Frank. "A finite sample correction for the variance of linear efficient twostep GMM estimators.” Journal of Econometrics 126 (1) (2005): 25-51.

World Bank. "World Development Indicators (WDI)." http://data.worldbank.org/datacatalog/world-development-indicators. Accessed November 30 (2012).

Zeileis, Achim, and Torsten Hothorn. "Diagnostic Checking in Regression Relationships." R News 2 (3) (2002): 7-10. 


\section{Appendix 1: Countries included in the sample}

\begin{tabular}{|l|l|l|}
\hline Albania & Greece & Netherlands \\
\hline Armenia & Hungary & New Zealand \\
\hline Australia & Iceland & Norway \\
\hline Austria & Ireland & Poland \\
\hline Azerbaijan & Israel & Portugal \\
\hline Belarus & Italy & Romania \\
\hline Belgium & Japan & Russian Federation \\
\hline Bosnia and Herzegovina & Kazakhstan & Serbia \\
\hline Bulgaria & Korea Republic & Slovak Republic \\
\hline Canada & Kosovo & Slovenia \\
\hline Chile & Kyrgyz Republic & Spain \\
\hline Croatia & Latvia & Switzerland \\
\hline Cyprus & Lithuania & Tajikistan \\
\hline Czech Republic & Luxembourg & Turkey \\
\hline Estonia & Macedonia, FYR & Turkmenistan \\
\hline Finland & Malta & Ukraine \\
\hline France & Mexico & United States \\
\hline Georgia & Moldova & Uzbekistan \\
\hline Germany & Montenegro & \\
\hline
\end{tabular}

(Note) The sample used to separately study the euro area and European Union enlargement includes Denmark, Sweden, and UK. 


\begin{tabular}{|c|c|c|c|c|c|c|c|c|c|c|c|c|c|c|c|c|c|c|c|}
\hline$\approx$ & 惡 & そ) & そ) & 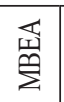 & そ & そ) & $\begin{array}{l}\text { 䍇 } \\
\text { 帘 }\end{array}$ & 䄈 & 至 & 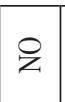 & そ & 总 & 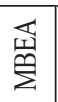 & $\begin{array}{l}\text { 至 } \\
\end{array}$ & \begin{tabular}{|l|}
\multirow{4}{*}{} \\
妥 \\
\end{tabular} & $\begin{array}{l}\text { 嵌 } \\
\text { 䍃 }\end{array}$ & $\begin{array}{l}\text { 正 } \\
\sum \\
\sum\end{array}$ & そ) & 缼 \\
\hline క్ & 面 & そ & そ) & 畓 & そ) & そ) & $\begin{array}{l}\text { 缼 } \\
\text { 空 }\end{array}$ & 㞯 & 剀 & 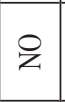 & そ) & 렁 & 嵒 & 至 & 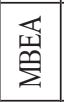 & 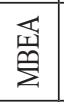 & $\begin{array}{l}\mathbb{1} \\
\sum \\
\Sigma\end{array}$ & そ) & $\begin{array}{l}\text { 荇 } \\
\text { 帘 }\end{array}$ \\
\hline 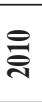 & 罸 & そ) & $\stackrel{0}{z}$ & 垃 & そ) & そ) & $\begin{array}{l}\text { 丽 } \\
\text { 竞 }\end{array}$ & 㤐 & 至 & そ & $\stackrel{\wp}{z}$ & 芑 & 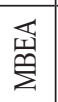 & 元 & 至 & 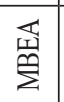 & 面 & $\stackrel{\wp}{z}$ & 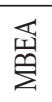 \\
\hline క్షి & 罳 & そ) & そ) & 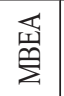 & \% & そ) & $\begin{array}{l}\text { 舀 } \\
\text { 空 }\end{array}$ & 总 & 宛 & Z & $\stackrel{\wp}{z}$ & 㞯 & 嵒 & 恁 & 出 & 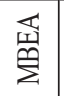 & $\begin{array}{l}\mathbb{1} \\
\sum \\
\sum\end{array}$ & $\stackrel{\circ}{z}$ & $\begin{array}{l}\text { 缼 } \\
\text { 空 }\end{array}$ \\
\hline 束 & 炡 & そ & そ) & 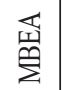 & そ & そ) & 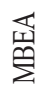 & 芑 & 㺼 & $\stackrel{\wp}{2}$ & そ & 㞯 & $\begin{array}{l}\text { 䠗 } \\
\end{array}$ & 恁 & 顽 & $\begin{array}{l}\overrightarrow{1} \\
\text { 愛 }\end{array}$ & $\begin{array}{l}\text { 要 } \\
\text { 产 }\end{array}$ & 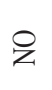 & 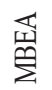 \\
\hline 8 & 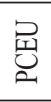 & そ & そ) & $\begin{array}{l} \\
\text { 焉 } \\
\end{array}$ & そ & そ) & 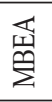 & 总 & 颉 & $\stackrel{\wp}{2}$ & そ & 㞯 & 凷 & 凷 & 至 & 斐 & $\begin{array}{l}\mathbb{1} \\
\sum \\
\Sigma\end{array}$ & そ) & $\begin{array}{l}\text { 젚 } \\
\text { 齐 }\end{array}$ \\
\hline छั & 㞯 & そ) & そ) & 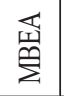 & そ & そ) & $\begin{array}{l}\text { 䍃 } \\
\sum\end{array}$ & 总 & 导 & $\stackrel{\wp}{2}$ & そ & 导 & 䂒 & 恁 & 忘 & 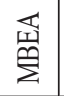 & $\begin{array}{l}\underset{1}{\mid c} \\
\sum \\
\Sigma\end{array}$ & そ & 嵒 \\
\hline "ֶิ & 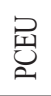 & そ & そ) & 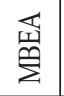 & そ) & $\stackrel{\wp}{2}$ & 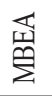 & 䆥 & 芑 & $\stackrel{\wp}{2}$ & そ) & 祑 & 䂒 & 恁 & 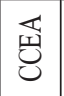 & 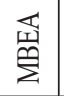 & 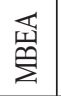 & そ) & 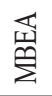 \\
\hline \pm & 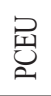 & そ & そ) & 攻 & そ) & そ & $\begin{array}{l}\text { 舀 } \\
\text { 旁 }\end{array}$ & 芑 & 㞯 & 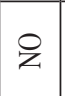 & そ & 㞯 & 顽 & 䂒 & 箊 & 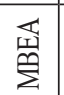 & 焉 & そ & 㫃 \\
\hline ڤ్తి & 罢 & そ & そ) & 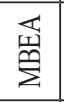 & そ & そ) & $\begin{array}{l}\text { 至 } \\
\text { 䍃 }\end{array}$ & ? & 㞯 & $\stackrel{\wp}{2}$ & そ & 㞯 & 总 & 茎 & 㿿 & 焉 & 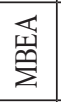 & そ) & 荇 \\
\hline ฮิ & そ) & そ) & そ) & 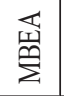 & そ & そ) & 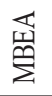 & そ) & 㞯 & $\stackrel{\wp}{2}$ & そ & 㞯 & 㞯 & 㠰 & 勇 & 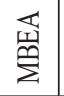 & 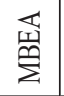 & そ & 嵒 \\
\hline$\overline{\bar{\beth}}$ & $\stackrel{\wp}{Z}$ & そ & そ) & $\begin{array}{l}\text { 垔 } \\
\text { 妾 }\end{array}$ & そ) & そ) & $\begin{array}{l}\text { 缶 } \\
\text { 空 }\end{array}$ & $\stackrel{\wp}{z}$ & 苞 & そ) & そ) & 茎 & 矛 & 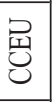 & 王 & 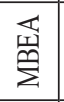 & 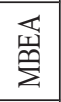 & そ & 荇 \\
\hline ట్రి & そ & そ) & そ) & 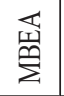 & そ) & そ) & $\begin{array}{l}\text { 至 } \\
\text { 离 }\end{array}$ & そ & 坖 & Z & そ) & そ) & 总 & 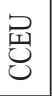 & 兒 & 垃 & $\begin{array}{l}\text { 年 } \\
\text { 䍃 }\end{array}$ & そ & 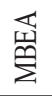 \\
\hline Бิ & そ) & そ & そ & 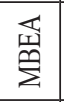 & そ & そ) & $\begin{array}{l}\text { 缼 } \\
\sum\end{array}$ & ㅇ & પ્યુ & $\stackrel{\wp}{2}$ & そ & そ) & 总 & 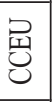 & 至 & 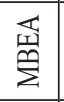 & 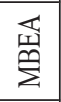 & そ) & 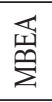 \\
\hline హొ & そ) & そ) & そ) & 㜽 & そ) & そ) & 记 & そ) & 壳 & $\stackrel{\wp}{2}$ & そ & そ) & 异 & 矛 & 㤩 & 志 & 荇 & そ & 苂 \\
\hline g & $\stackrel{\wp}{Z}$ & そ & $\stackrel{\wp}{Z}$ & 顽 & そ) & $\stackrel{\wp}{Z}$ & 至 & $\bar{z}$ & 忢 & $\stackrel{\wp}{Z}$ & そ) & そ) & $\begin{array}{l}\text { 㤩 } \\
\text {. }\end{array}$ & $\begin{array}{l}\text { 鬲 } \\
\text { : }\end{array}$ & \begin{tabular}{|l} 
\\
至 \\
2 \\
\end{tabular} & 㳋 & 岳 & $\stackrel{\wp}{Z}$ & 凷 \\
\hline よ้ & $\stackrel{0}{z}$ & そ) & $\stackrel{\wp}{Z}$ & 顽 & そ) & そ) & 䂒 & そ) & પ્ટુ & $\stackrel{\wp}{Z}$ & そ) & $\stackrel{\wp}{Z}$ & 㤩 & 㤩 & 胥 & 參 & 至 & $\stackrel{\wp}{z}$ & 凷 \\
\hline נٍ & 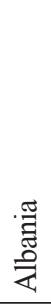 & 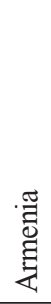 & 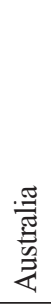 & 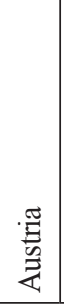 & 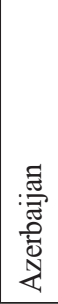 & 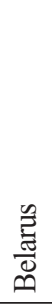 & 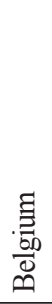 & 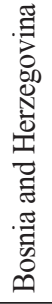 & 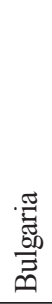 & 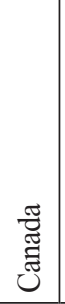 & 竘 & 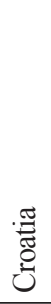 & 总 & 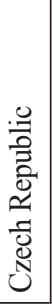 & 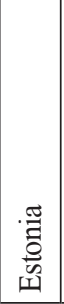 & $\begin{array}{c}\vec{\Xi} \\
\underset{\Xi}{\Xi} \\
\text { 吉 }\end{array}$ & 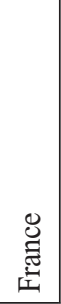 & 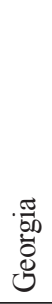 & 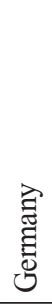 \\
\hline
\end{tabular}




\begin{tabular}{|c|c|c|c|c|c|c|c|c|c|c|c|c|c|c|c|c|c|c|c|}
\hline & 徳 & 䒴 & 8 & $\frac{100}{2}$ & $\bar{z}$ & 镸 & $\bar{z}$ & $z$ & o & $\begin{array}{l}\text { 曾 } \\
\end{array}$ & \& & Bi & 挹 & 商 & & 莹 & & & \\
\hline & 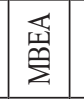 & है & 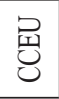 & 訔 & $\stackrel{8}{z}$ & 崽 & $q_{z}^{g}$ & 8 & 8 & \begin{tabular}{|l} 
曾 \\
\end{tabular} & $\stackrel{\gtrless}{z}$ & 惌 & 畓 & \begin{tabular}{l|l} 
畄 \\
\end{tabular} & 䍖 & 可 & そ & & \\
\hline & 畄 & & & $\frac{\bar{m}}{2}$ & $\stackrel{8}{z}$ & 畄 & \& & 9 & & 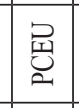 & \& & 苾 & 要 & 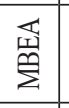 & 䍘 & 递 & z & & \\
\hline & में & ] & 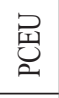 & 畺 & 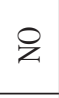 & 辤 & \& & & & 鳥 & 8 & 惌 & 夏 & $\begin{array}{l}\frac{⿱}{19} \\
\frac{1}{2}\end{array}$ & 罚 & 递 & \& & & \\
\hline & & & 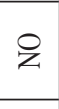 & 畺 & \& & 畺 & 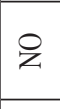 & 8 & & $\mid$ & $q$ & 苾 & 苾 & 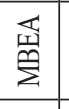 & 导 & 畩 & 8 & 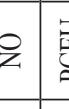 & \\
\hline & & & z & 诚 & $\stackrel{\gtrless}{z}$ & 畄 & そ & \& & & $q_{1}$ & そ & 煾 & 畄 & 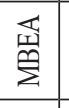 & 导 & 要 & \& & 8 & \\
\hline & 푭 & & \& & \begin{tabular}{|} 
嘼 \\
\end{tabular} & そ & 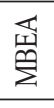 & そ & そ & & \& & 8 & 急 & 急 & $\begin{array}{l} \\
\\
\end{array}$ & 忌 & 密 & 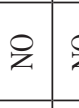 & 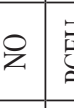 & \\
\hline & 西 & & 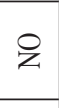 & 繒 & \& & $\begin{array}{l}\text { 戛 } \\
\end{array}$ & 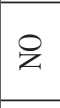 & z & & 8 & $q$ & 急 & 急 & 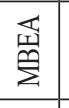 & 旡 & 密 & 8 & 8 & \\
\hline & 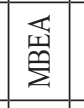 & & 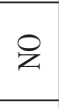 & 剀 & $\nexists$ & $\begin{array}{l}\text { 畄 } \\
\end{array}$ & そ & 8 & & ๑ & 8 & \begin{tabular}{|l|l|} 
悤 \\
\end{tabular} & 畄 & 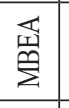 & 旡 & 要 & \& & 8 & \\
\hline & 畄 & & $\bar{z}$ & 8 & $\stackrel{\gtrless}{\not}$ & 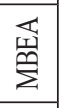 & そ & z & & z & 8 & 層 & \begin{tabular}{|l|} 
\\
\end{tabular} & 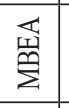 & 兽 & 总 & \& & 8 & \\
\hline & 4 & & 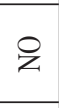 & 2 & 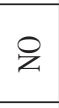 & $\begin{array}{l}\text { 罴 } \\
\end{array}$ & そ & \& & 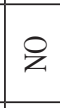 & z & \& & $\begin{array}{l}0 \\
\\
3\end{array}$ & 蛋 & 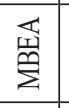 & 胥 & 啰 & 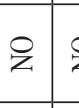 & $\nexists$ & \\
\hline & 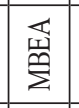 & ¿ & 4 & 2 & $\stackrel{\gtrless}{z}$ & 畄 & ৪ & 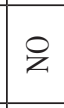 & & $\circ$ & 0 & U. & 䍘 & $\begin{array}{l} \\
\end{array}$ & 思 & 总 & 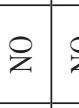 & 8 & \\
\hline & 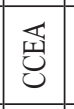 & & $\stackrel{̊}{z}$ & $\Sigma$ & $\gtreqless$ & 眔 & ஜ & 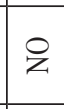 & & 0 & \& & 10 & \begin{tabular}{|l|l|} 
导 \\
\end{tabular} & 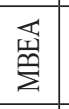 & 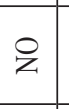 & 总 & 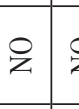 & $\stackrel{8}{z}$ & \\
\hline & 8 & ¿ & 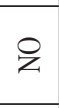 & $\begin{array}{l}\text { 啇 } \\
\end{array}$ & 4 & 眔 & 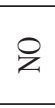 & $\nexists$ & & 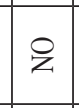 & & & \begin{tabular}{|l|l|} 
惫 \\
\end{tabular} & 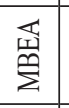 & 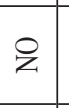 & 总 & z & \& & \\
\hline & & & 2 & 离 & z & 畠 & 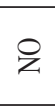 & $z$ & 12 & $z$ & 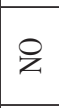 & & \begin{tabular}{|l|l|}
$己$ \\
\end{tabular} & 胥 & $\stackrel{2}{2}$ & 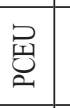 & 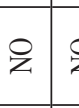 & $\mathrm{z}^{2}$ & \\
\hline & & & z & E & そ & 要 & 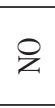 & z & & $\mathrm{z}$ & 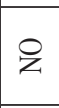 & & \begin{tabular}{l|} 
惫 \\
\end{tabular} & 苾 & 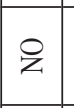 & 芭 & $\stackrel{z}{z}$ & $\mathrm{z}=$ & \\
\hline & 雷 & & そ & & $\circ$ & 䍃 & ฉ & \& & \& & 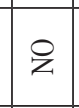 & ஓ & & $\begin{array}{l}\text { 惫 } \\
\end{array}$ & 苾 & & 㿿 & そ & 8 & \\
\hline & & & & & & & & & & & & & & 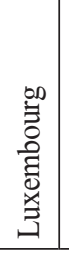 & & & & & 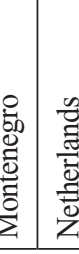 \\
\hline
\end{tabular}




\begin{tabular}{|c|c|c|c|c|c|c|c|c|c|c|c|c|c|c|c|c|c|}
\hline בี & そ & そ & 㓙 & 窗 & 吕 & そ) & 핑 & 空 & 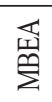 & 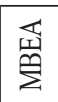 & そ & ○ & 펑 & そ & そ & そ) & 0 \\
\hline$\Xi$ & そ & そ & 芯 & $\begin{array}{l}\text { 出 } \\
\text { 空 }\end{array}$ & 䓈 & ○ & 品 & 嵒 & $\begin{array}{l}\mathbb{1} \\
\text { 䍃 }\end{array}$ & 画 & そ & そ & 罣 & そ & そ & そ) & \\
\hline$\stackrel{\varrho}{\theta}$ & そ & z & 昏 & 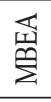 & 㐏 & $\circ$ & ? & 覓 & 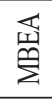 & 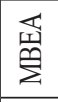 & そ) & z & 疍 & ○ & そ) & そ) & \\
\hline 8 & そ) & z & 㺼 & $\begin{array}{l}\text { 出 } \\
\text { 竞 }\end{array}$ & 恁 & ○ & ? & 嵒 & 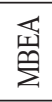 & 㟧 & そ) & z & 茎 & 乙 & そ) & そ) & \\
\hline$\infty$ & そ & そ & 颉 & 丽 & 元 & ᄋ & $?$ & 恄 & 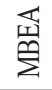 & 䙑 & そ) & そ & 总 & ○ & そ & そ) & \\
\hline$z$ & そ & そ & 范 & $\begin{array}{l}\text { 至 } \\
\text { 空 }\end{array}$ & 䂒 & 0 & 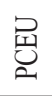 & 画 & $\begin{array}{l}\mathbb{1} \\
\text { 䍃 }\end{array}$ & 嵒 & そ & そ & 䍖 & $\stackrel{0}{z}$ & そ & そ) & \\
\hline 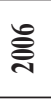 & そ & Z & 氶 & 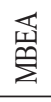 & 总 & ○ & $?$ & 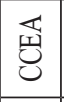 & 坖 & 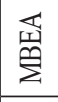 & そ & そ & & $\stackrel{\circ}{z}$ & そ) & そ) & \\
\hline$\stackrel{6}{E}$ & そ) & そ) & 売 & 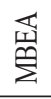 & ?깅 & 0 & & 䂒 & 范 & 㑩 & そ & Z & & そ & そ) & そ) & \\
\hline$\ddot{\Delta}$ & そ & 0 & 茳 & 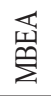 & ? & 0 & & 䂒 & 出 & 描 & そ & ○ & & ○ & そ & そ) & \\
\hline$\hat{\varepsilon}$ & そ & 0 & ? & $\begin{array}{l}\text { 至 } \\
\text { 空 }\end{array}$ & 㠰 & そ) & & 勇 & 窐 & 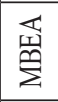 & そ & そ & 㞯 & そ & そ & そ) & \\
\hline 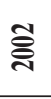 & Z & $\circ$ & 芑 & 㟧 & ? & ○ & そ & 苞 & 勇 & 颃 & そ & そ & & そ & そ & そ) & \\
\hline $\bar{\theta}$ & z & 0 & ? & 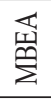 & ? & $\stackrel{0}{z}$ & そ & 至 & 胥 & 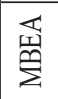 & そ & 足 & & そ & そ & そ) & \\
\hline 8 & 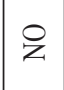 & そ & P & 丽 & ? & そ) & そ & 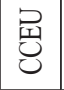 & 視 & 裋 & そ & F & & $\stackrel{\wp}{2}$ & そ & 8 & \\
\hline & Z & そ & ? & 荝 & $\overrightarrow{\mid r}$ & そ) & そ & 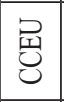 & 勇 & 画 & そ & z & 罣 & そ & そ & そ) & \\
\hline & Z & そ & ? & 剀 & 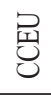 & そ) & そ & 窇 & 足 & 壱 & そ & $z$ & & そ & そ & そ) & \\
\hline & $\stackrel{c}{z}$ & $\stackrel{\circ}{z}$ & 2 & 売 & 定 & & 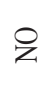 & 罣 & ? & 頊 & そ & 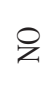 & & $z$ & そ) & $\stackrel{\wp}{Z}$ & \\
\hline & $\stackrel{g}{z}$ & & 2 & 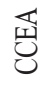 & 触 & & そ & E & ? & 壵 & $\bar{z}$ & z & & $z$ & そ) & そ) & \\
\hline & 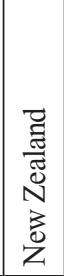 & $\overrightarrow{3}$ & $\begin{array}{l}\vec{E} \\
\frac{\text { ज्ञ }}{0} \\
\text { e }\end{array}$ & 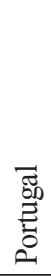 & 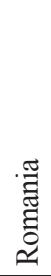 & 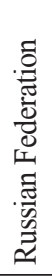 & 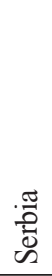 & 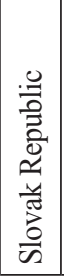 & 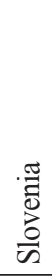 & $\begin{array}{l}\text { ज्ञ } \\
\text { कू. }\end{array}$ & 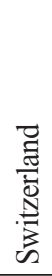 & 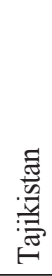 & 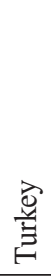 & 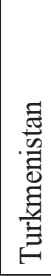 & 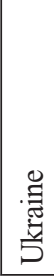 & 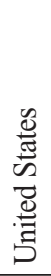 & \\
\hline
\end{tabular}

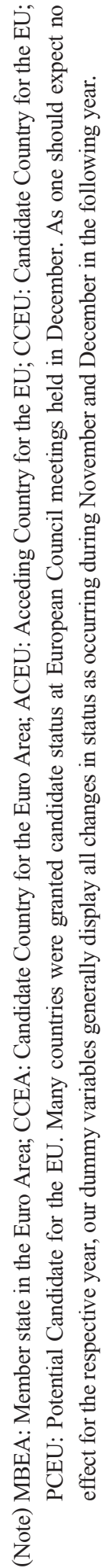




\section{Appendix 3: Least-squares estimates}

(with biannual data)

\begin{tabular}{|c|c|c|c|c|c|c|}
\hline \multirow{2}{*}{ Independent variables } & \multicolumn{6}{|c|}{ Dependent variables } \\
\hline & VaA & $\mathrm{CoC}$ & GE & PSNV & RoL & RQ \\
\hline $\operatorname{lag}(W G I)$ & $\begin{array}{l}0.4740^{* * *} \\
(0.0370)\end{array}$ & $\begin{array}{l}0.5148^{* * *} \\
(0.0465)\end{array}$ & $\begin{array}{l}0.6133^{* * *} \\
(0.0611)\end{array}$ & $\begin{array}{l}0.2881^{* * *} \\
(0.0642)\end{array}$ & $\begin{array}{l}0.5870^{* * *} \\
(0.0648)\end{array}$ & $\begin{array}{l}0.4713^{* * *} \\
(0.0664)\end{array}$ \\
\hline $\operatorname{lag}(P C E U)$ & $\begin{array}{c}0.0564 \\
(0.0469)\end{array}$ & $\begin{array}{c}0.0332 \\
(0.0663)\end{array}$ & $\begin{array}{c}0.0364 \\
(0.0457)\end{array}$ & $\begin{array}{c}0.0810 \\
(0.1057)\end{array}$ & $\begin{array}{l}0.0851 \\
(0.0389)\end{array}$ & $\begin{array}{l}0.0931^{* *} \\
(0.0364)\end{array}$ \\
\hline $\operatorname{lag}(C C E U)$ & $\begin{array}{l}0.2364 \\
(0.0853)\end{array}$ & $\begin{array}{c}0.0946 \\
(0.1033)\end{array}$ & $\begin{array}{l}0.1865^{* * *} \\
(0.0471)\end{array}$ & $\begin{array}{l}0.1832^{*} \\
(0.0970)\end{array}$ & $\begin{array}{l}0.0909 \\
(0.0399)\end{array}$ & $\begin{array}{c}0.0977 \\
(0.0762)\end{array}$ \\
\hline $\operatorname{lag}(C C E A)$ & $\begin{array}{c}0.1348 \\
(0.0969)\end{array}$ & $\begin{array}{c}0.0489 \\
(0.1094)\end{array}$ & $\begin{array}{c}0.1269^{*} \\
(0.0712)\end{array}$ & $\begin{array}{c}0.1037 \\
(0.1322)\end{array}$ & $\begin{array}{c}0.1130 \\
(0.0584)\end{array}$ & $\begin{array}{c}0.0565 \\
(0.1091)\end{array}$ \\
\hline $\operatorname{lag}(M B E A)$ & $\begin{array}{c}0.0585 \\
(0.1256)\end{array}$ & $\begin{array}{l}-0.2698 \\
(0.1239)\end{array}$ & $\begin{array}{c}0.0580 \\
(0.0830)\end{array}$ & $\begin{array}{l}-0.2083 \\
(0.1647)\end{array}$ & $\begin{array}{c}0.0215 \\
(0.0607)\end{array}$ & $\begin{array}{c}0.1134 \\
(0.1397)\end{array}$ \\
\hline lag (GDP per capita US) & $\begin{array}{l}-0.0732 \\
(0.0667)\end{array}$ & $\begin{array}{c}0.0788 \\
(0.0738)\end{array}$ & $\begin{array}{l}0.1885^{* * *} \\
(0.0663)\end{array}$ & $\begin{array}{l}0.4788 \\
(0.1108)\end{array}$ & $\begin{array}{l}0.1811 \\
(0.0660)\end{array}$ & $\begin{array}{l}0.2602^{* * x} \\
(0.0862)\end{array}$ \\
\hline $\operatorname{lag}($ Trade $)$ & $\begin{array}{c}0.0492 \\
(0.0540)\end{array}$ & $\begin{array}{c}0.0562 \\
(0.0700)\end{array}$ & $\begin{array}{c}0.1008 \\
(0.0827)\end{array}$ & $\begin{array}{c}0.1251 \\
(0.1050)\end{array}$ & $\begin{array}{c}0.0993^{*} \\
(0.0593)\end{array}$ & $\begin{array}{c}0.1068 \\
(0.0701)\end{array}$ \\
\hline $\operatorname{lag}(W G I)^{*} \operatorname{lag}(P C E U)$ & $\begin{array}{l}-0.0164 \\
(0.0807)\end{array}$ & $\begin{array}{l}-0.1013 \\
(0.0700)\end{array}$ & $\begin{array}{l}-0.0441 \\
(0.0529)\end{array}$ & $\begin{array}{l}-0.0538 \\
(0.0770)\end{array}$ & $\begin{array}{l}-0.0109 \\
(0.0478)\end{array}$ & $\begin{array}{l}-0.0016 \\
(0.0718)\end{array}$ \\
\hline $\operatorname{lag}(W G I) * \operatorname{lag}(C C E U)$ & $\begin{array}{c}-0.2252^{* * *} \\
(0.0666)\end{array}$ & $\begin{array}{c}-0.2334^{* * *} \\
(0.0509)\end{array}$ & $\begin{array}{c}-0.2312^{* * *} \\
(0.0514)\end{array}$ & $\begin{array}{c}-0.2956 \\
(0.0723)\end{array}$ & $\begin{array}{c}-0.1214^{* * *} \\
(0.0358)\end{array}$ & $\begin{array}{l}-0.0584 \\
(0.1002)\end{array}$ \\
\hline $\operatorname{lag}(W G I)^{*} \operatorname{lag}(C C E A)$ & $\begin{array}{l}-0.1035 \\
(0.0881)\end{array}$ & $\begin{array}{l}-0.0705 \\
(0.0563)\end{array}$ & $\begin{array}{l}-0.0161 \\
(0.0565)\end{array}$ & $\begin{array}{l}-0.0894 \\
(0.1001)\end{array}$ & $\begin{array}{l}-0.0405 \\
(0.0410)\end{array}$ & $\begin{array}{l}-0.0095 \\
(0.1069)\end{array}$ \\
\hline $\operatorname{lag}(W G I)^{*} \operatorname{lag}(M B E A)$ & $\begin{array}{l}-0.0633 \\
(0.1092)\end{array}$ & $\begin{array}{c}0.0738 \\
(0.0624) \\
\end{array}$ & $\begin{array}{l}-0.0675 \\
(0.0632) \\
\end{array}$ & $\begin{array}{c}0.0345 \\
(0.1013) \\
\end{array}$ & $\begin{array}{l}-0.0173 \\
(0.0474) \\
\end{array}$ & $\begin{array}{l}-0.0894 \\
(0.1024) \\
\end{array}$ \\
\hline$R^{2}$ & 0.3632 & 0.4089 & 0.5512 & 0.2963 & 0.5422 & 0.3643 \\
\hline Adjusted $R^{2}$ & 0.3017 & 0.3393 & 0.4572 & 0.2457 & 0.4500 & 0.3020 \\
\hline Number of observations & 437 & 435 & 434 & 433 & 435 & 433 \\
\hline
\end{tabular}

(Notes) (i ) The columns display the results of six regressions; in each regression, one Worldwide Governance Indicator (WGI) is the dependent variable. Additionally, its lag is used as an independent variable.

(ii) $*$, ** and $* * *$ indicate significance at the $10 \%, 5 \%$ and $1 \%$ level, respectively; $\operatorname{lag}()$ denotes lagged one period; sample: 1996 2012, biannual, 56 countries, unbalanced panel because of data availability; two-way within OLS estimator; panel robust standard errors are reported in parentheses.

(iii) VaA: Voice and Accountability, CoC: Control of Corruption, GE: Government Effectiveness, PSNV: Political Stability and Absence of Violence, RoL: Rule of Law, RQ: Regulatory Quality.

(iv) The abbreviations are the statuses of European countries, PCEU: Potential Candidate for EU, CCEU: Candidate Country for EU, CCEA: Candidate Country for Euro Area, MBEA: Member state in the Euro Area. 


\section{Appendix 4: Least-squares estimates}

(with the European Union-accession-related dummies)

\begin{tabular}{|c|c|c|c|c|c|c|}
\hline \multirow{2}{*}{ Independent variables } & \multicolumn{6}{|c|}{ Dependent variables } \\
\hline & $\mathbf{V a A}$ & $\mathrm{CoC}$ & GE & PSNV & RoL & RQ \\
\hline $\operatorname{lag}(W G I)$ & $\begin{array}{l}0.8009^{* * *} \\
(0.0198)\end{array}$ & $\begin{array}{l}0.7870^{* * *} \\
(0.0221)\end{array}$ & $\begin{array}{l}0.7998^{* * *} \\
(0.0352)\end{array}$ & $\begin{array}{l}0.7043^{* * *} \\
(0.0348)\end{array}$ & $\begin{array}{l}0.8216^{* * *} \\
(0.0297)\end{array}$ & $\begin{array}{l}0.7821^{* * *} \\
(0.0314)\end{array}$ \\
\hline $\operatorname{lag}(P C E U)$ & $\begin{array}{l}-0.0226 \\
(0.0266)\end{array}$ & $\begin{array}{c}0.0197 \\
(0.0221)\end{array}$ & $\begin{array}{c}0.0326 \\
(0.0260)\end{array}$ & $\begin{array}{c}0.0417 \\
(0.0331)\end{array}$ & $\begin{array}{c}0.0358 \\
(0.0244)\end{array}$ & $\begin{array}{l}0.0525^{* * *} \\
(0.0185)\end{array}$ \\
\hline $\operatorname{lag}(C C E U)$ & $\begin{array}{c}0.0655 \\
(0.0528)\end{array}$ & $\begin{array}{c}0.0487 \\
(0.0441)\end{array}$ & $\begin{array}{l}0.1253^{* * *} \\
(0.0267)\end{array}$ & $\begin{array}{l}0.1007^{* *} \\
(0.0405)\end{array}$ & $\begin{array}{l}0.04466^{*} \\
(0.0256)\end{array}$ & $\begin{array}{c}0.0429 \\
(0.0411)\end{array}$ \\
\hline $\operatorname{lag}(A C E U)$ & $\begin{array}{l}0.1852^{* *} \\
(0.0828)\end{array}$ & $\begin{array}{c}0.0337 \\
(0.0811)\end{array}$ & $\begin{array}{c}0.0750 \\
(0.0498)\end{array}$ & $\begin{array}{c}0.0551 \\
(0.0809)\end{array}$ & $\begin{array}{l}0.0823^{* *} \\
(0.0405)\end{array}$ & $\begin{array}{l}0.1970^{* * *} \\
(0.0713)\end{array}$ \\
\hline $\operatorname{lag}(M B E U)$ & $\begin{array}{c}0.0385 \\
(0.0501)\end{array}$ & $\begin{array}{c}0.0042 \\
(0.0469)\end{array}$ & $\begin{array}{l}0.0855^{* *} \\
(0.0370)\end{array}$ & $\begin{array}{c}0.0559 \\
(0.0542)\end{array}$ & $\begin{array}{l}0.0621^{*} \\
(0.0361)\end{array}$ & $\begin{array}{c}0.0387 \\
(0.0485)\end{array}$ \\
\hline $\operatorname{lag}(G D P$ per capita US $)$ & $\begin{array}{l}-0.0337 \\
(0.0309)\end{array}$ & $\begin{array}{c}0.0659^{*} \\
(0.0389)\end{array}$ & $\begin{array}{l}0.1481 \\
(0.0420)\end{array}$ & $\begin{array}{l}0.2343^{* * *} \\
(0.0591)\end{array}$ & $\begin{array}{l}0.1000 \\
(0.0380)\end{array}$ & $\begin{array}{l}0.1282^{* *} \\
(0.0435)\end{array}$ \\
\hline $\operatorname{lag}($ Trade $)$ & $\begin{array}{c}0.0166 \\
(0.0252)\end{array}$ & $\begin{array}{c}0.0436 \\
(0.0315)\end{array}$ & $\begin{array}{c}0.0614 \\
(0.0424)\end{array}$ & $\begin{array}{c}0.1112 \\
(0.0679)\end{array}$ & $\begin{array}{l}0.0651^{* *} \\
(0.0272)\end{array}$ & $\begin{array}{l}0.0814^{* *} \\
(0.0331)\end{array}$ \\
\hline $\operatorname{lag}(W G I)^{*} \operatorname{lag}(P C E U)$ & $\begin{array}{c}0.0035 \\
(0.0451)\end{array}$ & $\begin{array}{l}-0.0400 \\
(0.0312)\end{array}$ & $\begin{array}{c}-0.0777^{* * *} \\
(0.0273)\end{array}$ & $\begin{array}{l}-0.0310 \\
(0.0347)\end{array}$ & $\begin{array}{l}-0.0351^{*} \\
(0.0192)\end{array}$ & $\begin{array}{l}-0.0609 \\
(0.0396)\end{array}$ \\
\hline $\operatorname{lag}(W G I)^{*} \operatorname{lag}(C C E U)$ & $\begin{array}{l}-0.1025^{* *} \\
(0.0510)\end{array}$ & $\begin{array}{l}-0.0924 \\
(0.0247)\end{array}$ & $\begin{array}{c}-0.1382^{* * *} \\
(0.0277)\end{array}$ & $\begin{array}{l}-0.1103^{* * *} \\
(0.0389)\end{array}$ & $\begin{array}{l}-0.0710 \\
(0.0195)\end{array}$ & $\begin{array}{l}-0.0510 \\
(0.0524)\end{array}$ \\
\hline $\operatorname{lag}(W G I)^{*} \operatorname{lag}(A C E U)$ & $\begin{array}{c}-0.2680 \\
(0.0879)\end{array}$ & $\begin{array}{l}-0.0525 \\
(0.1179)\end{array}$ & $\begin{array}{l}-0.1346^{* * *} \\
(0.0444)\end{array}$ & $\begin{array}{c}-0.1778 \\
(0.0872)\end{array}$ & $\begin{array}{l}-0.1670 \\
(0.0435)\end{array}$ & $\begin{array}{l}-0.2053 \\
(0.0668)\end{array}$ \\
\hline $\operatorname{lag}(W G I)^{*} \operatorname{lag}(M B E U)$ & $\begin{array}{l}-0.0757 \\
(0.0506) \\
\end{array}$ & $\begin{array}{c}0.0049 \\
(0.0389) \\
\end{array}$ & $\begin{array}{l}-0.0395 \\
(0.0276)\end{array}$ & $\begin{array}{l}-0.0473 \\
(0.0480) \\
\end{array}$ & $\begin{array}{c}-0.0560 \\
(0.0256) \\
\end{array}$ & $\begin{array}{l}-0.0451 \\
(0.0417) \\
\end{array}$ \\
\hline$R^{2}$ & 0.7239 & 0.7054 & 0.7213 & 0.5876 & 0.7774 & 0.6935 \\
\hline Adjusted $R^{2}$ & 0.6571 & 0.6401 & 0.6544 & 0.5329 & 0.7054 & 0.6291 \\
\hline Number of observations & 921 & 918 & 916 & 913 & 918 & 915 \\
\hline
\end{tabular}

(Notes) (i) The columns display the results of six regressions; in each regression, one Worldwide Governance Indicator (WGI) is the dependent variable. Additionally, its lag is used as an independent variable.

(ii) $*, * *$ and $* * *$ indicate significance at the $10 \%, 5 \%$ and $1 \%$ level, respectively; lag() denotes lagged one period; sample: 1996 2012, 59 countries, unbalanced panel because of data availability; twoway within OLS estimator; panel robust standard errors are reported in parentheses.

(iii) VaA: Voice and Accountability, CoC: Control of Corruption, GE: Government Effectiveness, PSNV: Political Stability and Absence of Violence, RoL: Rule of Law, RQ: Regulatory Quality.

(iv) The abbreviations are the statuses of European countries, PCEU: Potential Candidate for EU, CCEU: Candidate Country for EU, ACEU: Acceding Country for EU, MBEA: Member state in the Euro Area. 


\section{Appendix 5: Least-squares estimates}

(with the euro-area-related dummies)

\begin{tabular}{|c|c|c|c|c|c|c|}
\hline \multirow{2}{*}{ Independent variables } & \multicolumn{6}{|c|}{ Dependent variables } \\
\hline & $\mathbf{V a A}$ & $\mathrm{CoC}$ & GE & PSNV & RoL & RQ \\
\hline $\operatorname{lag}(W G I)$ & $\begin{array}{l}0.7858^{* * *} \\
(0.0177)\end{array}$ & $\begin{array}{l}0.7667^{* * *} \\
(0.0250)\end{array}$ & $\begin{array}{l}0.7869^{* * *} \\
(0.0336)\end{array}$ & $\begin{array}{l}0.6855^{* * *} \\
(0.0341)\end{array}$ & $\begin{array}{l}0.8147^{* * *} \\
(0.0275)\end{array}$ & $\begin{array}{l}0.7753^{* * *} \\
(0.0254)\end{array}$ \\
\hline $\operatorname{lag}(C C E A)$ & $\begin{array}{c}-00.0155 \\
(0.0417)\end{array}$ & $\begin{array}{c}-00.0145 \\
(0.0188)\end{array}$ & $\begin{array}{c}-00.0160 \\
(0.0169)\end{array}$ & $\begin{array}{c}0.0270 \\
(0.0385)\end{array}$ & $\begin{array}{c}0.0017 \\
(0.0212)\end{array}$ & $\begin{array}{c}-00.0180 \\
(0.0478)\end{array}$ \\
\hline $\operatorname{lag}(M B E A)$ & $\begin{array}{c}-00.0040 \\
(0.0682)\end{array}$ & $\begin{array}{l}-00.1328^{* * *} \\
(0.0447)\end{array}$ & $\begin{array}{c}-00.0027 \\
(0.0373)\end{array}$ & $\begin{array}{c}-00.0768 \\
(0.0592)\end{array}$ & $\begin{array}{c}0.0026 \\
(0.0230)\end{array}$ & $\begin{array}{c}0.0203 \\
(0.0595)\end{array}$ \\
\hline $\operatorname{lag}($ GDP per capita US $)$ & $\begin{array}{c}-00.0461 \\
(0.0303)\end{array}$ & $\begin{array}{c}0.0433 \\
(0.0378)\end{array}$ & $\begin{array}{l}0.1239^{* * *} \\
(0.0414)\end{array}$ & $\begin{array}{l}0.2065^{* * *} \\
(0.0610)\end{array}$ & $\begin{array}{l}0.0996 \\
(0.0394)\end{array}$ & $\begin{array}{l}0.1362^{* * * *} \\
(0.0442)\end{array}$ \\
\hline $\operatorname{lag}($ Trade $)$ & $\begin{array}{c}0.0115 \\
(0.0272)\end{array}$ & $\begin{array}{c}0.0436 \\
(0.0335)\end{array}$ & $\begin{array}{c}0.0708^{*} \\
(0.0389)\end{array}$ & $\begin{array}{c}0.1174^{*} \\
(0.0697)\end{array}$ & $\begin{array}{l}0.0794^{* * *} \\
(0.0280)\end{array}$ & $\begin{array}{l}0.0936 \\
(0.0322)\end{array}$ \\
\hline $\operatorname{lag}(W G I)^{*} \operatorname{lag}(C C E A)$ & $\begin{array}{c}0.0152 \\
(0.0414)\end{array}$ & $\begin{array}{c}0.0370 \\
(0.0228)\end{array}$ & $\begin{array}{l}0.0614^{* *} \\
(0.0262)\end{array}$ & $\begin{array}{c}-00.0272 \\
(0.0395)\end{array}$ & $\begin{array}{c}0.0150 \\
(0.0216)\end{array}$ & $\begin{array}{c}0.0048 \\
(0.0459)\end{array}$ \\
\hline $\operatorname{lag}(W G I)^{*} \operatorname{lag}(M B E A)$ & $\begin{array}{c}-00.0031 \\
(0.0609)\end{array}$ & $\begin{array}{l}0.0843^{* *} \\
(0.0365)\end{array}$ & $\begin{array}{c}0.0049 \\
(0.0338)\end{array}$ & $\begin{array}{c}0.0000 \\
(0.0498)\end{array}$ & $\begin{array}{c}-00.0039 \\
(0.0222)\end{array}$ & $\begin{array}{c}-00.0338 \\
(0.0441)\end{array}$ \\
\hline$R^{2}$ & 0.7166 & 0.7057 & 0.7153 & 0.5842 & 0.7707 & 0.6893 \\
\hline Adjusted $R^{2}$ & 0.6536 & 0.6435 & 0.6521 & 0.5324 & 0.7027 & 0.6283 \\
\hline Number of observations & 921 & 918 & 916 & 913 & 918 & 915 \\
\hline
\end{tabular}

(Notes) ( i) The columns display the results of six regressions; in each regression, one Worldwide Governance Indicator (WGI) is the dependent variable. Additionally, its lag is used as an independent variable.

(ii) $*$, ** and $* * *$ indicate significance at the $10 \%, 5 \%$ and $1 \%$ level, respectively; lag() denotes lagged one period; sample: 1996 2012, 59 countries, unbalanced panel because of data availability; twoway within OLS estimator; panel robust standard errors are reported in parentheses.

(iii) VaA: Voice and Accountability, CoC: Control of Corruption, GE: Government Effectiveness, PSNV: Political Stability and Absence of Violence, RoL: Rule of Law, RQ: Regulatory Quality.

(iv) The abbreviations are the statuses of European countries, CCEA : Candidate Country for Euro Area, MBEA: Member state in the Euro Area. 


\section{Appendix 6: Blundell-Bond system GMM estimates}

\begin{tabular}{|c|c|c|c|c|c|c|}
\hline \multirow{2}{*}{ Independent variables } & \multicolumn{6}{|c|}{ Dependent variables } \\
\hline & VaA & $\mathrm{CoC}$ & GE & PSNV & RoL & RQ \\
\hline $\operatorname{lag}(W G I)$ & $\begin{array}{l}0.8467^{* * *} \\
(0.0994)\end{array}$ & $\begin{array}{l}0.7871^{* * *} \\
(0.1017)\end{array}$ & $\begin{array}{l}0.7546^{* * *} \\
(0.0635)\end{array}$ & $\begin{array}{l}0.4909^{* * *} \\
(0.1158)\end{array}$ & $\begin{array}{l}0.8522^{* * *} \\
(0.0553)\end{array}$ & $\begin{array}{c}0.7771^{* * *} \\
(0.0693)\end{array}$ \\
\hline $\operatorname{lag}(P C E U)$ & $\begin{array}{l}0.1900^{* * *} \\
(0.0727)\end{array}$ & $\begin{array}{l}-0.0681 \\
(0.0692)\end{array}$ & $\begin{array}{c}0.0063 \\
(0.0448)\end{array}$ & $\begin{array}{l}-0.2821 \\
(0.2684)\end{array}$ & $\begin{array}{c}0.0673^{*} \\
(0.0397)\end{array}$ & $\begin{array}{c}0.0152 \\
(0.0634)\end{array}$ \\
\hline $\operatorname{lag}(C C E U)$ & $\begin{array}{c}0.1487^{*} \\
(0.0897)\end{array}$ & $\begin{array}{l}-0.0319 \\
(0.0760)\end{array}$ & $\begin{array}{c}0.0687 \\
(0.0425)\end{array}$ & $\begin{array}{l}-0.0606 \\
(0.1307)\end{array}$ & $\begin{array}{c}0.0261 \\
(0.0393)\end{array}$ & $\begin{array}{c}0.1052 \\
(0.0665)\end{array}$ \\
\hline $\operatorname{lag}(C C E A)$ & $\begin{array}{l}0.2164^{*} \\
(0.1218)\end{array}$ & $\begin{array}{l}-0.1615^{*} \\
(0.0969)\end{array}$ & $\begin{array}{l}-0.0040 \\
(0.0639)\end{array}$ & $\begin{array}{l}-0.1104 \\
(0.1819)\end{array}$ & $\begin{array}{c}0.0091 \\
(0.0408)\end{array}$ & $\begin{array}{c}0.0433 \\
(0.1362)\end{array}$ \\
\hline $\operatorname{lag}(M B E A)$ & $\begin{array}{l}0.3240 \\
(0.1202)\end{array}$ & $\begin{array}{l}-0.3387^{* *} \\
(0.1324)\end{array}$ & $\begin{array}{l}-0.1807 \\
(0.1112)\end{array}$ & $\begin{array}{l}-0.2382 \\
(0.2121)\end{array}$ & $\begin{array}{c}-0.1550 \\
(0.0702)\end{array}$ & $\begin{array}{c}0.0396 \\
(0.2049)\end{array}$ \\
\hline $\operatorname{lag}(W G I)^{*} \operatorname{lag}(P C E U)$ & $\begin{array}{c}-0.3812^{* *} \\
(0.1601)\end{array}$ & $\begin{array}{l}-0.1621^{* *} \\
(0.0803)\end{array}$ & $\begin{array}{l}-0.1063 \\
(0.0692)\end{array}$ & $\begin{array}{l}-0.0838 \\
(0.2259)\end{array}$ & $\begin{array}{c}0.0646 \\
(0.0470)\end{array}$ & $\begin{array}{c}0.0402 \\
(0.0944)\end{array}$ \\
\hline $\operatorname{lag}(W G I)^{*} \operatorname{lag}(C C E U)$ & $\begin{array}{c}-0.1818^{* *} \\
(0.0770)\end{array}$ & $\begin{array}{l}-0.1548^{* *} \\
(0.0630)\end{array}$ & $\begin{array}{l}-0.1779^{* * *} \\
(0.0426)\end{array}$ & $\begin{array}{l}-0.2096 \\
(0.1343)\end{array}$ & $\begin{array}{l}-0.0449 \\
(0.0373)\end{array}$ & $\begin{array}{l}-0.0973 \\
(0.0909)\end{array}$ \\
\hline $\operatorname{lag}(W G I)^{*} \operatorname{lag}(C C E A)$ & $\begin{array}{c}-0.2380^{*} \\
(0.1395)\end{array}$ & $\begin{array}{c}0.0638 \\
(0.0642) \\
\end{array}$ & $\begin{array}{c}0.0235 \\
(0.0513)\end{array}$ & $\begin{array}{l}-0.0554 \\
(0.1729)\end{array}$ & $\begin{array}{c}0.0332 \\
(0.0375)\end{array}$ & $\begin{array}{l}-0.0043 \\
(0.1152)\end{array}$ \\
\hline $\operatorname{lag}(W G I)^{*} \operatorname{lag}(M B E A)$ & $\begin{array}{c}-0.3090^{* *} \\
(0.1376)\end{array}$ & $\begin{array}{c}0.1419^{*} \\
(0.0781)\end{array}$ & $\begin{array}{c}0.0308 \\
(0.0776)\end{array}$ & $\begin{array}{l}-0.1165 \\
(0.1759)\end{array}$ & $\begin{array}{c}0.0801^{*} \\
(0.0465)\end{array}$ & $\begin{array}{l}-0.0510 \\
(0.1566)\end{array}$ \\
\hline $\operatorname{lag}(G D P$ per capita US $)$ & $\begin{array}{c}0.1444^{*} \\
(0.0769)\end{array}$ & $\begin{array}{l}0.1802^{* *} \\
(0.0914)\end{array}$ & $\begin{array}{l}0.2012^{* * * *} \\
(0.0600)\end{array}$ & $\begin{array}{l}0.3164 * \\
(0.1014)\end{array}$ & $\begin{array}{l}0.1084^{* *} \\
(0.0492)\end{array}$ & $\begin{array}{l}0.1319^{* * * *} \\
(0.0405)\end{array}$ \\
\hline $\operatorname{lag}($ Trade $)$ & $\begin{array}{c}0.0758 \\
(0.1347)\end{array}$ & $\begin{array}{c}0.0623 \\
(0.1213)\end{array}$ & $\begin{array}{c}0.0612 \\
(0.0940)\end{array}$ & $\begin{array}{l}0.5914^{* * *} \\
(0.1894)\end{array}$ & $\begin{array}{c}0.0662 \\
(0.0651)\end{array}$ & $\begin{array}{c}0.1317 \\
(0.1260)\end{array}$ \\
\hline $\mathrm{n}$ & 56 & 56 & 56 & 56 & 56 & 56 \\
\hline $\mathrm{T}$ & 9 & 9 & 9 & 9 & 9 & 9 \\
\hline Number of observations & 504 & 504 & 504 & 504 & 504 & 504 \\
\hline Number of instruments & 51 & 52 & 52 & 51 & 52 & 52 \\
\hline AR(2) Test: $x^{2}$ & 1.6569 & -1.2143 & 0.1045 & 0.3139 & 1.2358 & -0.1551 \\
\hline $\operatorname{AR}(2)$ Test: $p$-value & 0.0488 & 0.1123 & 0.4584 & 0.3768 & 0.1083 & 0.4384 \\
\hline Sargan Test: $\mathrm{x}^{2}$ & 38.1614 & 29.1348 & 26.6361 & 41.5503 & 35.2957 & 40.1432 \\
\hline Sargan Test: degree of freedom & 33 & 33 & 33 & 33 & 33 & 33 \\
\hline Sargan Test: $p$-value & 0.2463 & 0.6601 & 0.7754 & 0.1460 & 0.3602 & 0.1831 \\
\hline
\end{tabular}

(Notes) (i) The columns display the results of six regressions; in each regression, one Worldwide Governance Indicator (WGI) is the dependent variable. Additionally, its lag is used as an independent variable.

(ii) $*, * *$ and $* * *$ indicate significance at the $10 \%, 5 \%$ and $1 \%$ level, respectively; lag () denotes lagged one period; sample: 1996 2012, biannual, 56 countries, unbalanced panel because of data 
availability.

(iii) Two-step system GMM (Blundell, Bond 1998) estimation with Windmeijer (2005) finite-sample correction for standard errors. Lags 2 to 4 are used as instruments. Included exogenous variables (time dummies) are counted as instruments. The Arellano-Bond test for AR(2) in first differences is rejected for VaA and PSNV in this specification (p-values: 0.0137 for VaA, 0.0780 for PSNV). Therefore, we restrict the instruments to lags 3 to 5 for VaA and PSNV. The Arellano-Bond test for $\mathrm{AR}(3)$ in first differences is not rejected thereafter for VaA and PSNV. The two-step version of the Hansen-Sargan test for joint validity of the instruments does not reject the null hypothesis for all the Worldwide Governance Indicators.

(iv) VaA: Voice and Accountability, CoC: Control of Corruption, GE: Government Effectiveness, PSNV: Political Stability and Absence of Violence, RoL: Rule of Law, RQ: Regulatory Quality.

(v) The abbreviations are the statuses of European countries, PCEU: Potential Candidate for EU, CCEU: Candidate Country for EU, CCEA: Candidate Country for Euro Area, MBEA: Member state in the Euro Area. 